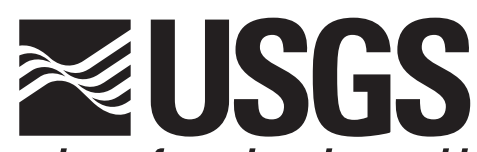

science for a changing world

Prepared in cooperation with the U.S. Environmental Protection Agency

\title{
Streamflow, Water Quality, and Metal Loads from Chat Leachate and Mine Outflow into Tar Creek, Ottawa County, Oklahoma, 2005
}

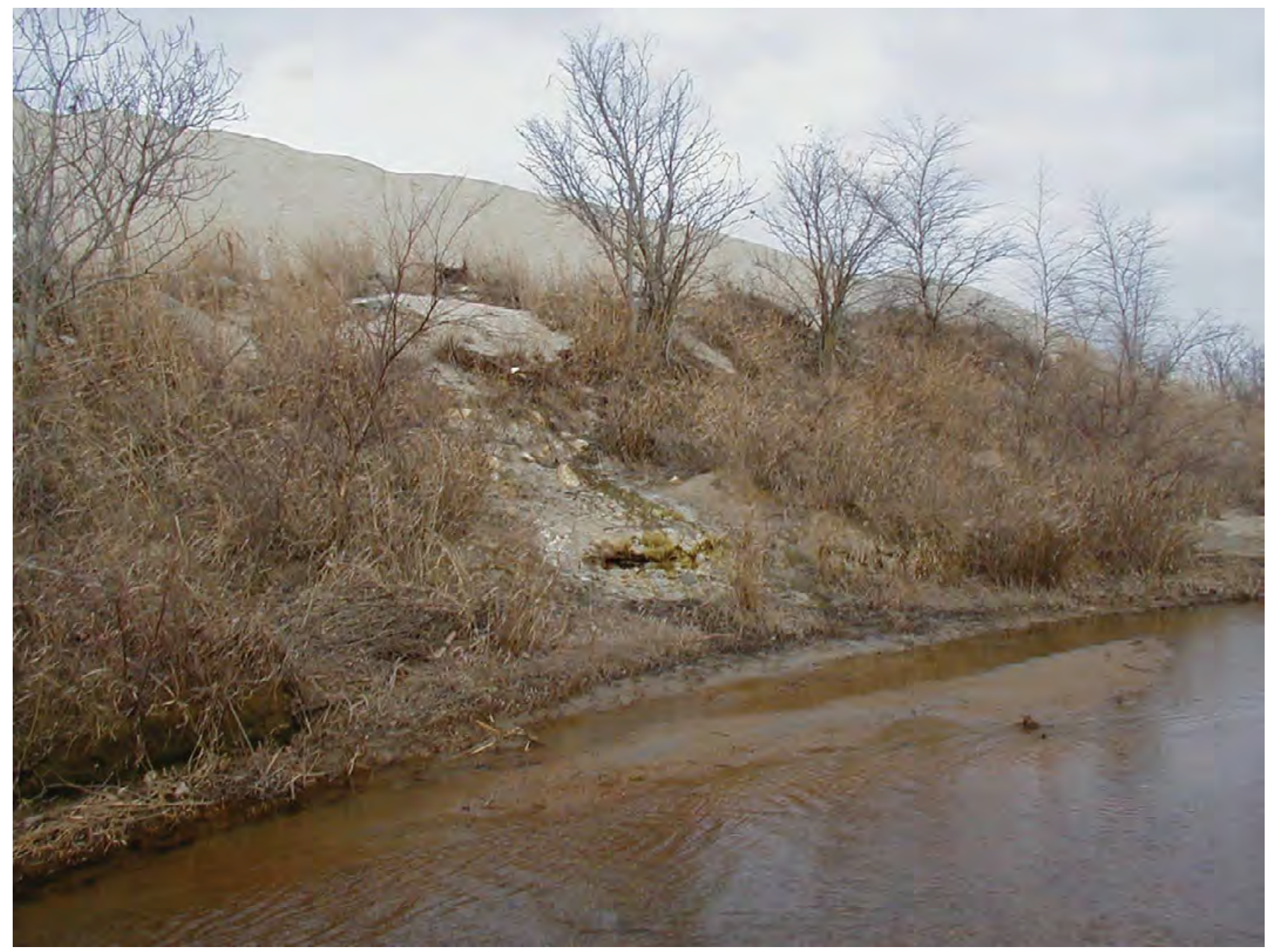

Scientific Investigations Report 2007-5115 
Cover: Photograph showing seepage from chat piles entering Tar Creek. Photograph taken by Mark Becker, U.S. Geological Survey. 


\section{Streamflow, Water Quality, and Metal Loads from Chat Leachate and Mine Outflow into Tar Creek, Ottawa County, Oklahoma, 2005}

By Caleb C. Cope, Mark F. Becker, William J. Andrews, and Kelli DeHay

Prepared in cooperation with the U.S. Environmental Protection Agency

Scientific Investigations Report 2007-5115 


\section{U.S. Department of the Interior \\ Dirk Kempthorne, Secretary \\ U.S. Geological Survey \\ Mark D. Meyers, Director}

U.S. Geological Survey, Reston, Virginia: 2008

For product and ordering information:

World Wide Web: http://www.usgs.gov/pubprod

Telephone: 1-888-ASK-USGS

For more information on the USGS — the Federal source for science about the Earth, its natural and living resources, natural hazards, and the environment:

World Wide Web: http://www.usgs.gov

Telephone: 1-888-ASK-USGS

Any use of trade, product, or firm names is for descriptive purposes only and does not imply endorsement by the U.S. Government.

Although this report is in the public domain, permission must be secured from the individual copyright owners to reproduce any copyrighted materials contained within this report.

Suggested citation:

Cope, C.C., Becker, M.F., Andrews, W.J., and DeHay, Kelli, 2008, Streamflow, Water Quality, and Metal Loads from Chat Leachate and Mine Outflow into Tar Creek, Ottawa County, Oklahoma, 2005: U.S. Geological Survey, Scientific Investigations Report 2007-5115, 23 p. 


\section{Contents}

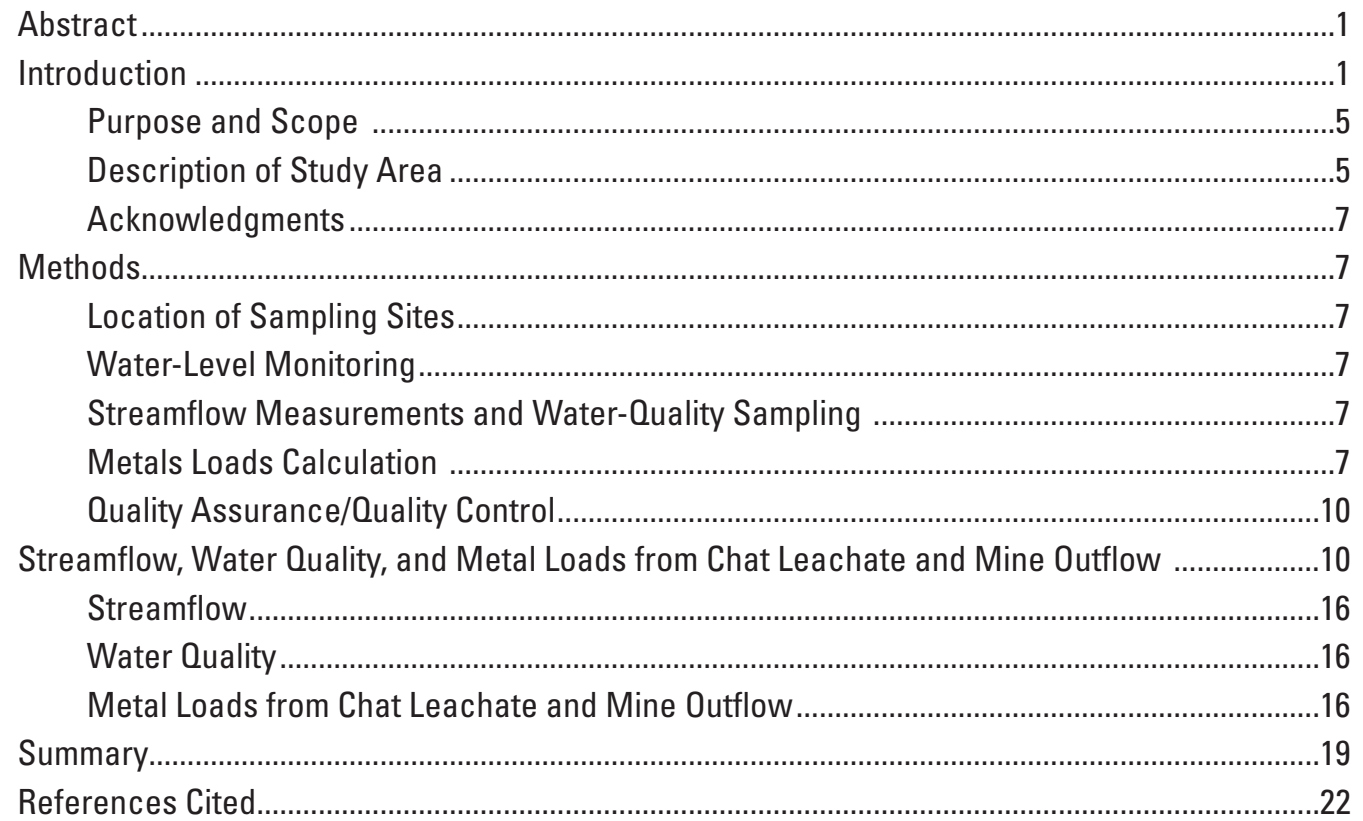

\section{Figures}

1a-1b. Maps showing:

1a. Location of study area in Ottawa County, Oklahoma.......................................2

1b. Location of sampling sites and wells in Tar Creek Study Segment, Ottawa

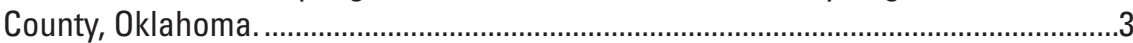

2. Photographs of : (A) tailings or "chat" pile near Picher, Oklahoma; (B) ironhydroxide-stained water along ditch draining to Tar Creek near Douthat, Oklahoma; and (C) fine-tailings in settling pond near Douthat, Oklahoma. ........................................

3-4. Map showing:

3. Location of sites in Tar Creek Study Segment, Ottawa County, Oklahoma........6 4. Location of transects 1 and 2 in the Tar Creek Study Segment, Ottawa County, Oklahoma.

5. Hydrographs showing precipitation, stream discharge, stream-water levels, and water elevations in the chat pile prior to and during the sampling period, August 16-29, 2005.

\section{Tables}

1. Station name, station number, and location of sampling sites in the Picher mining district, Ottawa County, Oklahoma.

2. Name and location of water-level monitoring wells in chat along Tar Creek in the Picher mining district, Ottawa County, Oklahoma.

3. Water levels measured during August 2005 in water-level monitoring wells, in the 
Picher mining district, Ottawa County, Oklahoma

4. Quality assurance/quality control data for samples collected from stations on Tar Creek, Lytle Creek, and the Western location, Picher mining district, Ottawa County, Oklahoma.

5. Streamflow and water-quality data from stations on Tar Creek, Lytle Creek, and the Western location, Picher mining district, Ottawa County, Oklahoma.

6. Calculated total and dissolved instantaneous metal loads from Tar Creek Study Segment in Ottawa County, Oklahoma.

7. Calculated total and dissolved metal loads from chat leachate and mine outflow to Tar Creek in the Picher mining district in Ottawa County Oklahoma..

8. Total estimated metal load for the 14-day sampling period and percentage from source for the Tar Creek Study Segment, Ottawa County, Oklahoma.

9. Summary statistics of metal loads and streamflow from Tar Creek above Douthat Bridge, near Cardin, Oklahoma (071850875) sampled from August 16, 2005, to August 29, 2005, in the Picher mining district, Ottawa County, Oklahoma.

\section{Conversion Factors and Datums}

\begin{tabular}{|c|c|c|}
\hline Multiply & By & To obtain \\
\hline \multicolumn{3}{|c|}{ Length } \\
\hline inch (in.) & 2.54 & centimeter $(\mathrm{cm})$ \\
\hline foot (ft) & 0.3048 & meter $(\mathrm{m})$ \\
\hline \multicolumn{3}{|c|}{ Volume } \\
\hline cubic foot $\left(\mathrm{ft}^{3}\right)$ & 0.02832 & cubic meter $\left(\mathrm{m}^{3}\right)$ \\
\hline \multicolumn{3}{|c|}{ Flow rate } \\
\hline cubic foot per second $\left(\mathrm{ft}^{3} / \mathrm{s}\right)$ & 0.02832 & cubic meter per second $\left(\mathrm{m}^{3} / \mathrm{s}\right)$ \\
\hline \multicolumn{3}{|c|}{ Mass } \\
\hline pound per day (lb/day) & 2000 & metric ton per day \\
\hline
\end{tabular}

Temperature in degrees Celsius $\left({ }^{\circ} \mathrm{C}\right)$ may be converted to degrees Fahrenheit $\left({ }^{\circ} \mathrm{F}\right)$ as follows:

$$
{ }^{\circ} \mathrm{F}=\left(1.8 x^{\circ} \mathrm{C}\right)+32
$$

Temperature in degrees Fahrenheit $\left({ }^{\circ} \mathrm{F}\right)$ may be converted to degrees Celsius $\left({ }^{\circ} \mathrm{C}\right)$ as follows:

$$
{ }^{\circ} \mathrm{C}=\left({ }^{\circ} \mathrm{F}-32\right) / 1.8
$$

Vertical coordinate information is referenced to National Geodetic Vertical Datum of 1929 (NGVD 29).

Horizontal coordinate information is referenced to North American Datum of 1983 (NAD 83) and North American Datum of 1927 (NAD 27).

Specific conductance is given in microsiemens per centimeter at 25 degrees Celsius $(\mu \mathrm{S} / \mathrm{cm}$ at $\left.25^{\circ} \mathrm{C}\right)$.

Concentrations of chemical constituents in water are given either in milligrams per liter (mg/L) or micrograms per liter $(\mu \mathrm{g} / \mathrm{L})$. 


\title{
Streamflow, Water Quality, and Metal Loads from Chat Leachate and Mine Outflow into Tar Creek, Ottawa County, Oklahoma, 2005
}

\author{
By Caleb C. Cope, Mark F. Becker, William J. Andrews, and Kelli DeHay
}

\section{Abstract}

Picher mining district is an abandoned lead and zinc mining area located in Ottawa County, northeastern Oklahoma. During the first half of the $20^{\text {th }}$ century, the area was a primary producer of lead and zinc in the United States. Large accumulations of mine tailings, locally referred to as chat, produce leachate containing cadmium, iron, lead, and zinc that enter drainages within the mining area. Metals also seep to local ground water and streams from unplugged shafts, vent holes, seeps, and abandoned mine dewatering wells. Streamflow measurements were made and water-quality samples were collected and analyzed from two locations in Picher mining district from August 16 to August 29 following a rain event beginning on August 14, 2005, to determine likely concentrations and loads of metals from tailings and mine outflows in the part of Picher mining district near Tar Creek.

Locations selected for sampling included a tailings pile with an adjacent mill pond, referred to as the Western location, and a segment of Tar Creek from above the confluence with Lytle Creek to below Douthat bridge, referred to as Tar Creek Study Segment. Measured streamflow was less than 0.01 cubic foot per second at the Western location, with streamflow only being measurable at that site on August 16, 2005. Measured streamflows ranged from $<0.01$ to 2.62 cubic feet per second at Tar Creek Study Segment.

One water-quality sample was collected from runoff at the Western location. Total metals concentrations in that sample were 95.3 micrograms per liter cadmium, 182 micrograms per liter iron, 170 micrograms per liter lead, 1,760 micrograms per liter zinc. Total mean metals concentrations in 29 waterquality samples collected from Tar Creek Study Segment from August 16-29, 2005, were 21.8 micrograms per liter cadmium, 7,924 micrograms per liter iron, 7.68 micrograms per liter lead, and 14,548 micrograms per liter zinc.

No metals loading values were calculated for the Western location. Metals loading to Tar Creek Study Segment were calculated based on instantaneous streamflow and metals concentrations. Total metals loading to Tar Creek from chat leachate ranged from 0.062 to 0.212 pound per day of cadmium,
$<0.001$ to 0.814 pound per day of iron, 0.003 to 0.036 pound per day of lead, and 10.6 to 47.9 pounds per day of zinc.

Metals loading to Tar Creek Study Segment from chat leachate and mine outflow was determined by subtracting values at appropriate upstream and downstream stations. Four sources of calculated metal loads are from Tar Creek and Lytle Creek entering the study segment, from chat pile leachate, and from old Lytle Creek mine outflow. Less than 1 percent of total and dissolved iron loading came from chat leachate, while about 99 percent of total iron loading came from mine outflow. Total and dissolved lead loading percentages from chat leachate were greater than total and dissolved lead loading percentages from mine outflow. About 19 percent of total zinc loading came from chat leachate, about 29 percent of total zinc loading came from mine outflow, and about 52 percent of total zinc loading came from Lytle Creek.

\section{Introduction}

Picher mining district, located in northeastern Ottawa County, Oklahoma (fig. 1), is part of Tri-State mining district, a 1,188-square-mile area in southwest Missouri, southeast Kansas, and northeast Oklahoma that was the most productive site of mining for sulfide ores of lead and zinc in the U.S. from the late 1830 s to the 1970 s, producing about 1.7 million tons of lead and 8.8 million tons of zinc (Gibson, 1972; Gibson, 1982; State of Oklahoma, 2000; and Robertson, 2006). Picher mining district, included in the initial National Priority list of Superfund sites as the Tar Creek Superfund site by the U.S. Environmental Protection Agency in 1983, is plagued by some of the most severe or widespread environmental degradation of any of the tens of thousands of abandoned mining sites in the U.S. (Ferderer, 1996; State of Oklahoma, 2000; and Robertson, 2006).

When mining stopped about 1979 , as much as $165-300$ million tons of mine tailings, some of which had been reprocessed one or more times to recover metals, remained in Picher mining district (State of Oklahoma, 2000). U.S. Army Corps of Engineers estimated in 2000 that 60 million cubic yards or 75 million tons of mine tailings remained in the 


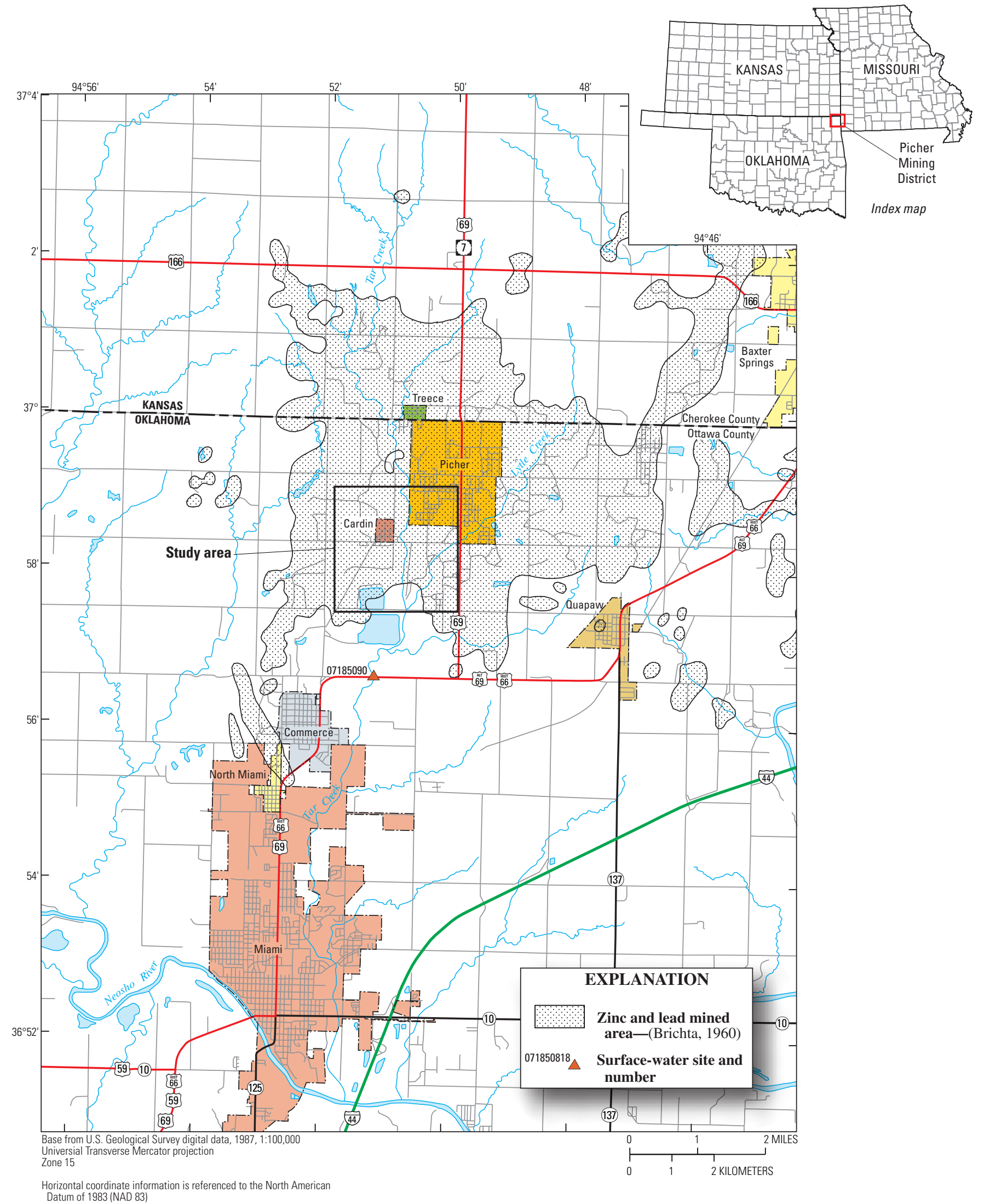

Figure 1a. Location of study area in Ottawa County, Oklahoma. 


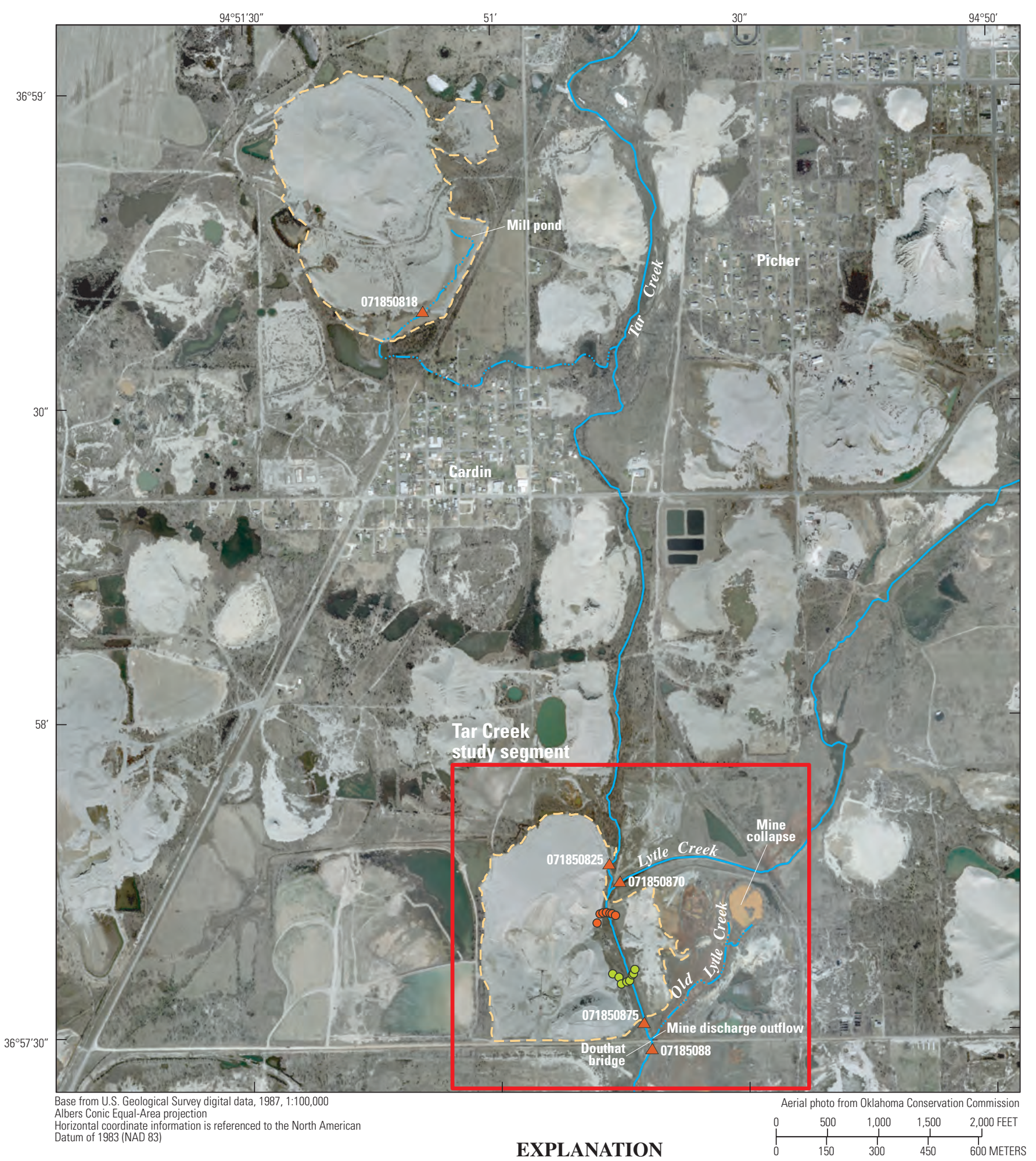

- - Approximate boundary of chat pile

071850818 $\triangle$ Surface-water site and number

- Shallow monitoring well-Transect 1

- Shallow monitoring well-Transect 2

Figure 1b. Location of sampling sites and wells in Tar Creek Study Segment, Ottawa County, Oklahoma. 
A.

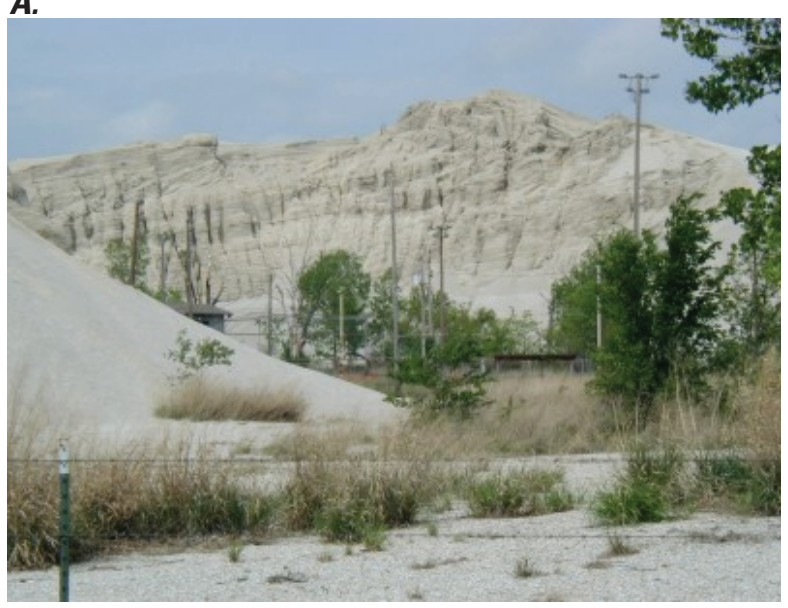

C.

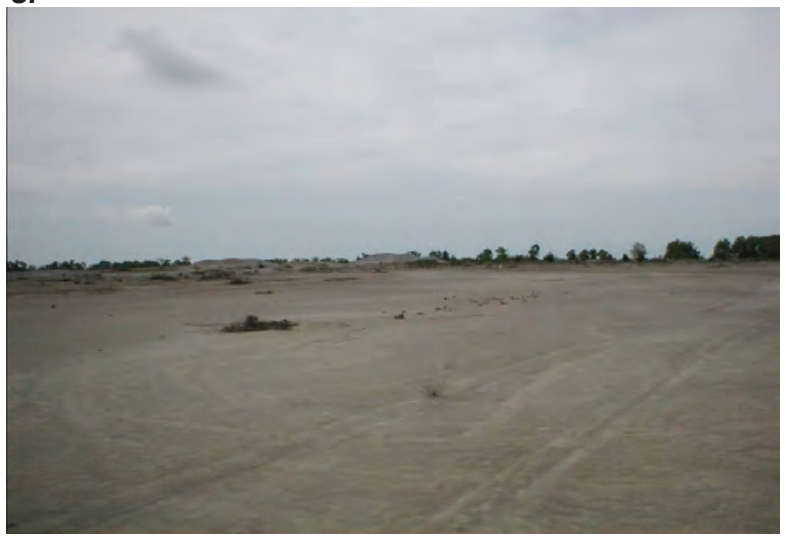

B.

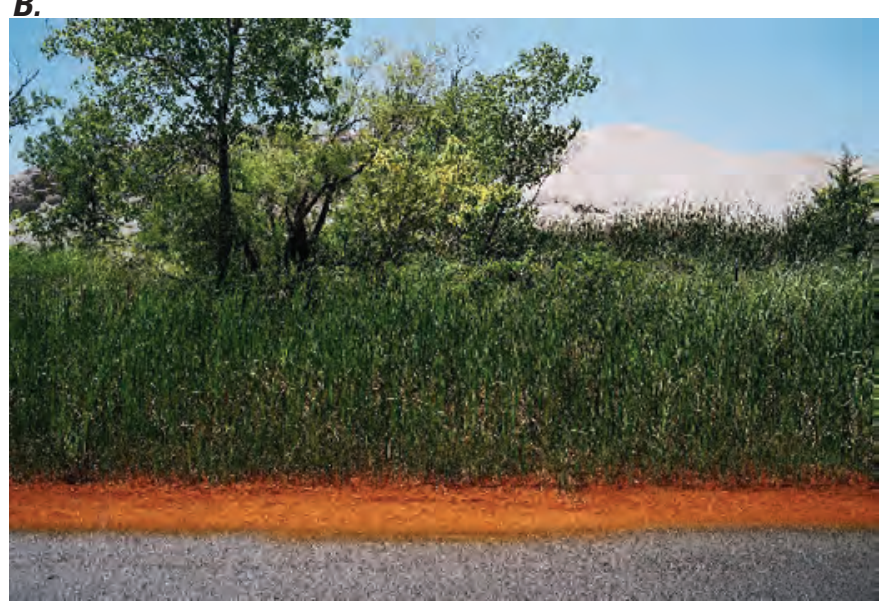

Figure 2. Photographs of : (A) tailings or "chat" pile near Picher, Oklahoma; (B) iron-hydroxide-stained water along ditch draining to Tar Creek near Douthat, Oklahoma; and (C) fine-tailings in settling pond near Douthat, Oklahoma. (Photographs by Robert W. Nairn, University of Oklahoma.)

district (State of Oklahoma, 2000). Large accumulations of gravel- to sand-sized mine tailings, locally referred to as chat, are present throughout the mining area (fig. 2). Ponds of siltand clay-sized by-products of the gravity separation process, referred to as mill pond wastes, are located near many of the chat piles. Chat and mill pond wastes contain metals associated with lead and zinc sulfide ores. Leachate from chat and mill pond wastes discharges to streams draining the mining area. Mining in the district occurred at depths below the water table, necessitating continuous pumping of ground water to prevent flooding of the workings. As mining ceased in the 1970s, those pumps were turned off, the mine workings filled with ground water, and seeps of water with large concentrations of metals started to flow at the land surface and drain to local streams in late 1979 (State of Oklahoma, 2002). Outflow of water from the mine workings occurs from several locations in the mining area, including unplugged mine shafts, vent holes, seeps, and abandoned mine dewatering wells. Metals from mine outflows can comprise a substantial contribution to the total metal loading of streams. Information about the amount of metal loading from chat and mill pond waste and mine outflow is needed to evaluate the fate and transport of metals in the mining district.

Picher mining district was placed on the National Priorities List in September 1983, as part of the Tar Creek Superfund Site, making the district a subject of evaluation and reclamation activities conducted under the Comprehensive Environmental Response, Compensation, and Liability Act of 1980 (CERCLA), otherwise known as "Superfund," which is administered by U.S. Environmental Protection Agency (EPA) and delegated state environmental agencies, such as Oklahoma Department of Environmental Quality (ODEQ). CERCLA establishes procedures under law for cleanup of hazardous waste sites and reimbursement for such cleanup by collection from responsible parties or a trust fund. An Administrative Order on Consent was entered into in 1983 between EPA, U.S. Department of Interior, and two former mining operators to investigate the mine and mill residues remaining at the site. EPA divides parts of a superfund site into Operable Units, which may refer to geographical parts of a site or specific site problems to be remediated. The investigation of mine and mill residues is designated by EPA Region 6 as Operable Unit 4 (Oklahoma Department of Environmental Quality, 2004).

U.S. Geological Survey (USGS), in cooperation with EPA, began a study in 2005 to characterize flow, collect waterquality data, and calculate loads of selected metals entering Tar Creek. Data collected for this report can be used to better 
understand the nature of metal loading to surface water systems adjacent to mine tailings and mine outflows.

\section{Purpose and Scope}

The purpose of this report is to characterize streamflow, water-quality, and metals loads discharged to Tar Creek from chat leachate and mine outflow at two locations in Picher mining district in August 2005. Locations selected for surfacewater sampling were: (1) drainage from an individual chat pile with an adjacent mill pond, referred to as the Western location, and (2) a segment of Tar Creek from above the confluence with Lytle Creek to below Douthat bridge, referred to as Tar Creek Study Segment location (figs. 1 and 3). The Western location contained one surface-water sampling site; whereas, Tar Creek Study Segment contained four surface-water sampling sites (fig. 1 and table 1). Sites were sampled over a 14-day period following a rainfall event until streamflow returned to pre-event status. One streamflow measurement was made and a water-quality sample was collected at the Western location. Seven streamflow measurements were made and seven water-quality samples were collected at each of the four sites in Tar Creek Study Segment.

Metal loading data are presented from two surface-water locations, one of which receives substantial water from an upstream mine outflow into Tar Creek. Instantaneous loads for total and dissolved cadmium, iron, lead, and zinc are calculated for samples collected. Results of this investigation will be used by EPA staff to estimate metal loading from chat leachate for the Remedial Investigation and Feasibility Study (RI/FS) for Operable Unit 4 of Tar Creek Superfund Site.

\section{Description of Study Area}

Picher mining district is located in northeastern Ottawa County (fig. 1) (McKnight and Fischer, 1970). Located upon flat prairie land between the Spring and Neosho Rivers near the Kansas/Oklahoma state line, the former mining communities of Picher, Commerce, Cardin, and Quapaw are included in the district (fig. 1).

Lytle Creek is the main tributary to Tar Creek (figs. 1 and 3). Originally Lytle Creek flowed into an open mine collapse before entering Tar Creek just above the Douthat bridge (fig. 3). Oklahoma Water Resources Board and EPA diverted the flow of Lytle Creek away from the mine collapse in the mid-1980s in an attempt to reduce recharge of metals-contaminated runoff water to the Boone aquifer (Keheley and Pritchard, 2000). Although the main channel of Lytle Creek has been diverted away from the collapse, a substantial amount of mine outflow enters Tar Creek through the old Lytle Creek channel. Base flow in Tar and Lytle Creeks throughout Picher mining district to the Douthat bridge is mostly maintained by discharges from chat pile leachate and mill ponds. Substantial volumes of mine outflow enter Tar Creek downstream from Douthat bridge to U.S. Highway 69.

Chat is deposited extensively throughout the Picher mining district. Chat is unconsolidated and highly permeable. Rainfall readily infiltrates chat and slowly seeps from the larger chat piles. Shale of the Krebs Group of Middle Pennsylvanian age underlies most of the land surface in the Picher mining district (McKnight and Fischer, 1970), creating a confining unit on top of which leachate from chat and millponds will tend to seep laterally to local streams. Rainfall reacts with the soluble minerals and mobilizes metals associated with residual ore minerals in the chat.

Table 1. Station name, station number, and location of sampling sites in the Picher mining district, Ottawa County, Oklahoma.

[dms, degrees minutes seconds; NAD 83, North American Datum of 1983; NAD 27, North American Datum of 1927]

\begin{tabular}{|c|c|c|c|c|}
\hline Station name & $\begin{array}{l}\text { Station } \\
\text { number }\end{array}$ & $\begin{array}{c}\text { Latitude } \\
\text { (dms) }\end{array}$ & $\begin{array}{l}\text { Longitude } \\
\text { (dms) }\end{array}$ & Datum \\
\hline Tar Creek near Cardin, Okla. & 071850825 & 365746 & 945047 & NAD 83 \\
\hline Lytle Creek near Cardin, Okla. & 071850870 & 365744 & 945046 & NAD 83 \\
\hline Tar Creek above Douthat Bridge, near Cardin, Okla. & 071850875 & 365731 & 945042 & NAD 83 \\
\hline Tar Creek near Picher, Okla. & 07185088 & 365729 & 945044 & NAD 27 \\
\hline Tar Creek Tributary at Western location & 071850818 & 365839 & 945108 & NAD 83 \\
\hline
\end{tabular}




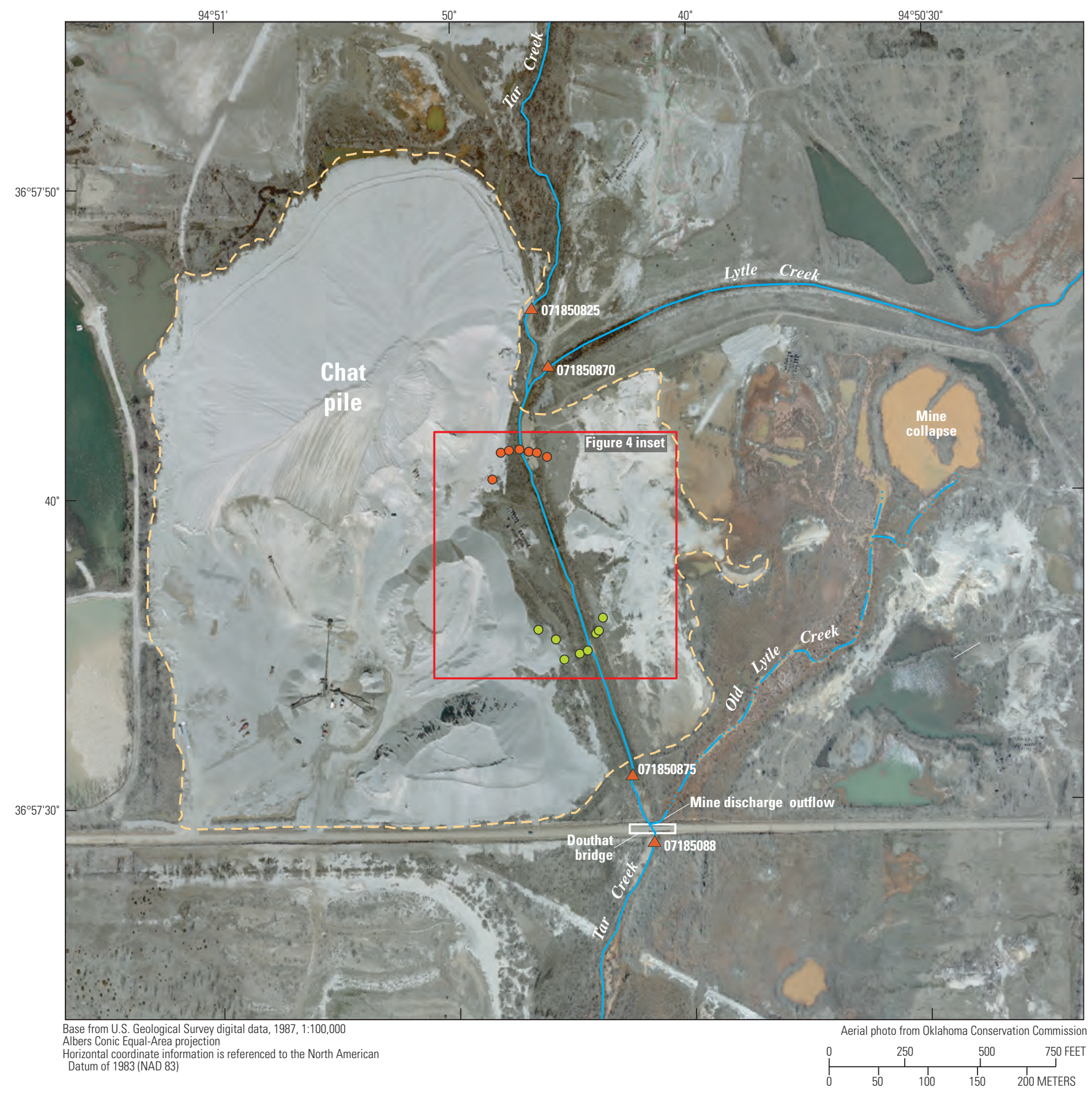

\section{EXPLANATION}

- - Approximate boundary of chat pile

${ }^{07185088} \triangle$ Surface-water site and number

- Shallow monitoring well-Transect 1

- Shallow monitoring well-Transect 2

Figure 3. Location of sites in Tar Creek Study Segment, Ottawa County, Oklahoma. 


\section{Acknowledgments}

Authors would like to thank all those who assisted in the collection of data for this report. Thanks to Sam Beets of the Bureau of Indian Affairs for access to the Western location. Gratitude is extended to Daniel Yeatts, Jerrod Smith, and Lyn Osburn, USGS, for their help in the review of the report, and to Tim Raines for technical support.

\section{Methods}

Ground-water levels were monitored in the chat over a two-week period following a rain event on August 14 and 15, 2005. Streamflow measurements and water-quality samples also were conducted and collected from Tar Creek and Lytle Creek during that two-week period. Metal loading values in pounds per day (lb/day) were calculated for cadmium, iron, lead, and zinc based on those streamflow measurements and water-quality data.

\section{Location of Sampling Sites}

Two locations were selected for surface-water sampling: Western location (Township 29N-Range 23E-Section 19) west of the town of Cardin, Oklahoma, and Tar Creek Study Segment (Township 29N-Range 23E-Sections 29 and 32) (fig. 1). The Western location contains one sampling site (071850818) (fig. 1 and table 1) located at a discharge point where a berm around a mill pond was breached and incised by previous runoff. Field reconnaissance indicated most of the runoff from the Western location flowed through that breach.

Tar Creek Study Segment is a reach of Tar Creek that passes through chat piles from above the confluence with Lytle Creek to Douthat bridge. Tar Creek Study Segment contains four sampling sites (071850825, 071850870, 071850875, and 07185088) (fig. 3 table 1). A substantial amount of mine outflow enters Tar Creek just above Douthat bridge from the old Lytle Creek channel (fig. 3). Samples collected at Tar Creek near Picher, Okla. (site 07185088) contain both leachate from chat piles and mine outflow.

\section{Water-Level Monitoring}

Shallow monitor wells were installed along two transects in the chat at Tar Creek Study Segment (figs. 1, 4, 5, and table 2). Fifteen wells were driven to a depth of up to 3 feet (ft) into chat. Ground-water levels were measured prior to surface-water sampling and during each day of surfacewater sampling (table 3), using an electric tape marked in increments of $0.01 \mathrm{ft}$ (fig. 5).

Two wells near the chat pile (TCW 1.3 and TCW 2.2) were instrumented with pressure transducers and data loggers to continuously record ground-water levels in chat and to monitor response of ground-water levels in chat to precipitation. Ground-water levels were assumed to have returned to pre-event levels, seepage of chat leachate to Tar Creek returned to pre-event rates.

\section{Streamflow Measurements and Water-Quality Sampling}

Streamflow measurements were made coincident with collection of water-quality samples. Streamflow measurements were made using acoustic Doppler profiler (ACDP) and conventional current meters in accordance with protocols described in Rantz and others (1982).

Water-quality samples were collected according to protocols described in USGS Techniques of Water-Resources Investigations (Wilde and Radtke, 1998 and 1999). Water properties were measured in the field in conjunction with each water-quality sample and streamflow measurement. Properties analyzed were: specific conductance, $\mathrm{pH}$, temperature, turbidity, dissolved oxygen, oxidation-reduction potential, and alkalinity.

Water-quality samples were placed in a churn splitter and homogenized for field processing. Samples to be analyzed for major ions and total metals were collected directly from the churn splitter. Samples to be analyzed for dissolved metals were passed through a 0.45 -micrometer pore size capsule filter. Samples to be analyzed for metals were preserved with nitric acid. Water samples were analyzed by USGS National Water Quality Laboratory (NWQL) in Lakewood, Colorado, for physical properties and for concentrations of dissolved major ions (calcium, magnesium, sodium, potassium, and sulfate), total metals (cadmium, iron, lead, and zinc) and dissolved metals (cadmium, iron, lead, and zinc). Major ion and metals concentrations were determined at NWQL by the inductively coupled plasma (ICP) method (Faires, 1993). Suspended sediment concentrations were analyzed by USGS sediment laboratory in Rolla, Missouri.

\section{Metals Loads Calculation}

Metals loading estimates in pound per day (lb/day) were calculated by the following equation:

Load $(\mathrm{lb} /$ day $)=$ streamflow $\left(\mathrm{ft}^{3} / \mathrm{s}\right) *$ metal concentration $(\mathrm{mg} / \mathrm{L}) * 5.393\left(\mathrm{lb} * \mathrm{sec}^{*} \mathrm{~L}\right) /\left(\mathrm{day}^{*} \mathrm{ft}^{3 * \mathrm{mg}}\right)$

where $\mathrm{lb} / \mathrm{day}=$ pound per day

$\mathrm{ft}^{3} / \mathrm{s}=$ cubic foot per second,

$\mathrm{mg} / \mathrm{L}=$ milligram per liter, and

$\mathrm{L}=$ liter

Metals in water in Tar Creek Study Segment were assumed to have originated from four sources: (1) Tar Creek above the study segment, (2) Lytle Creek, (3) leachate from adjacent chat pile, and (4) mine outflow from old Lytle Creek directly above Douthat bridge (fig. 3).

Estimated metals loading values entering the study segment from upper Tar Creek and Lytle Creek were calculated 


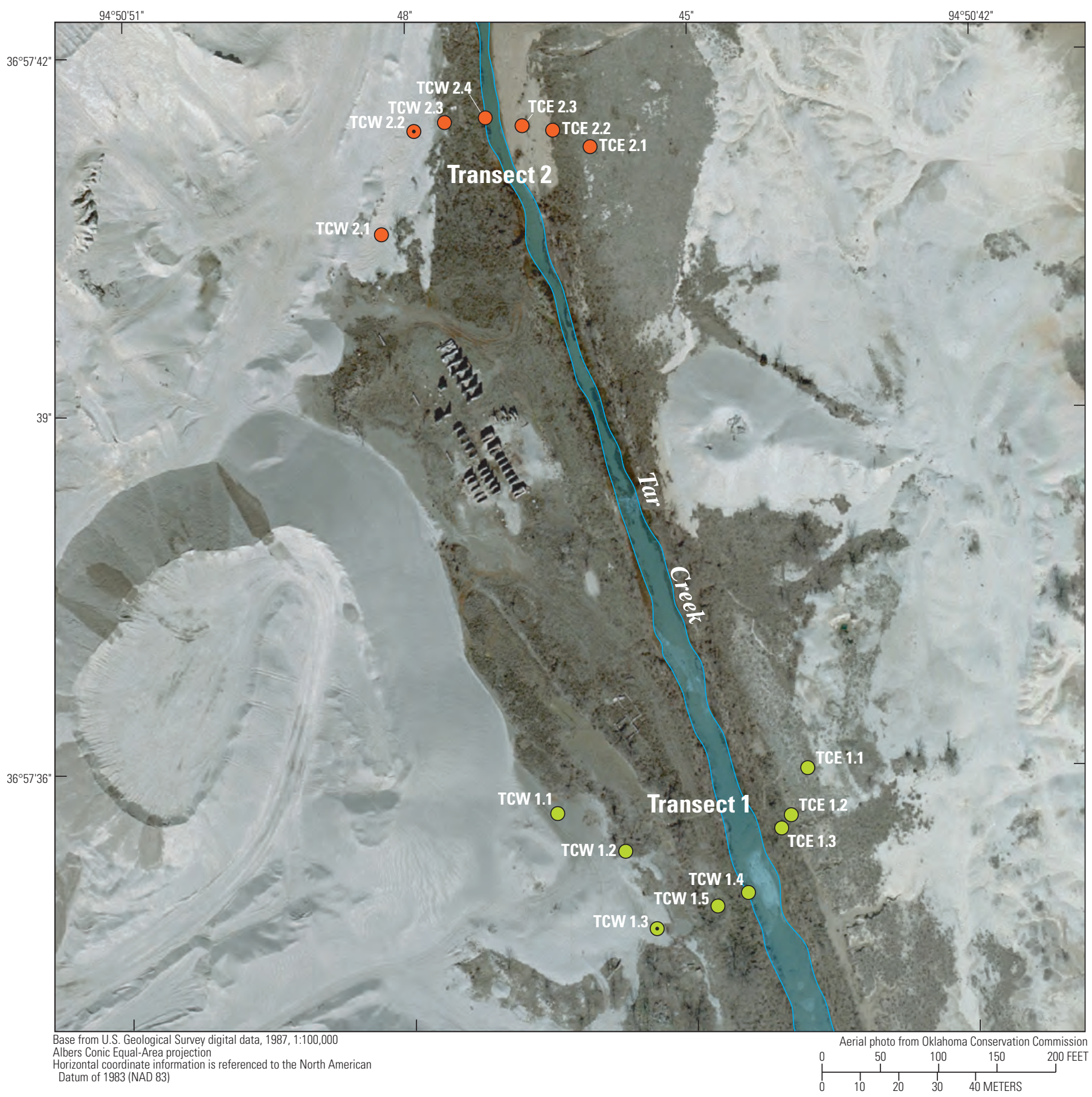

\section{EXPLANATION}

TCW 1.2 $\bigcirc$ Shallow monitoring well and identifier-Transect 1

TCW 2.1 Shallow monitoring well and identifier-Transect 2

$\odot \odot$ Shallow monitoring well with pressure transducer

Figure 4. Location of transects 1 and 2 in the Tar Creek Study Segment, Ottawa County, Oklahoma. 

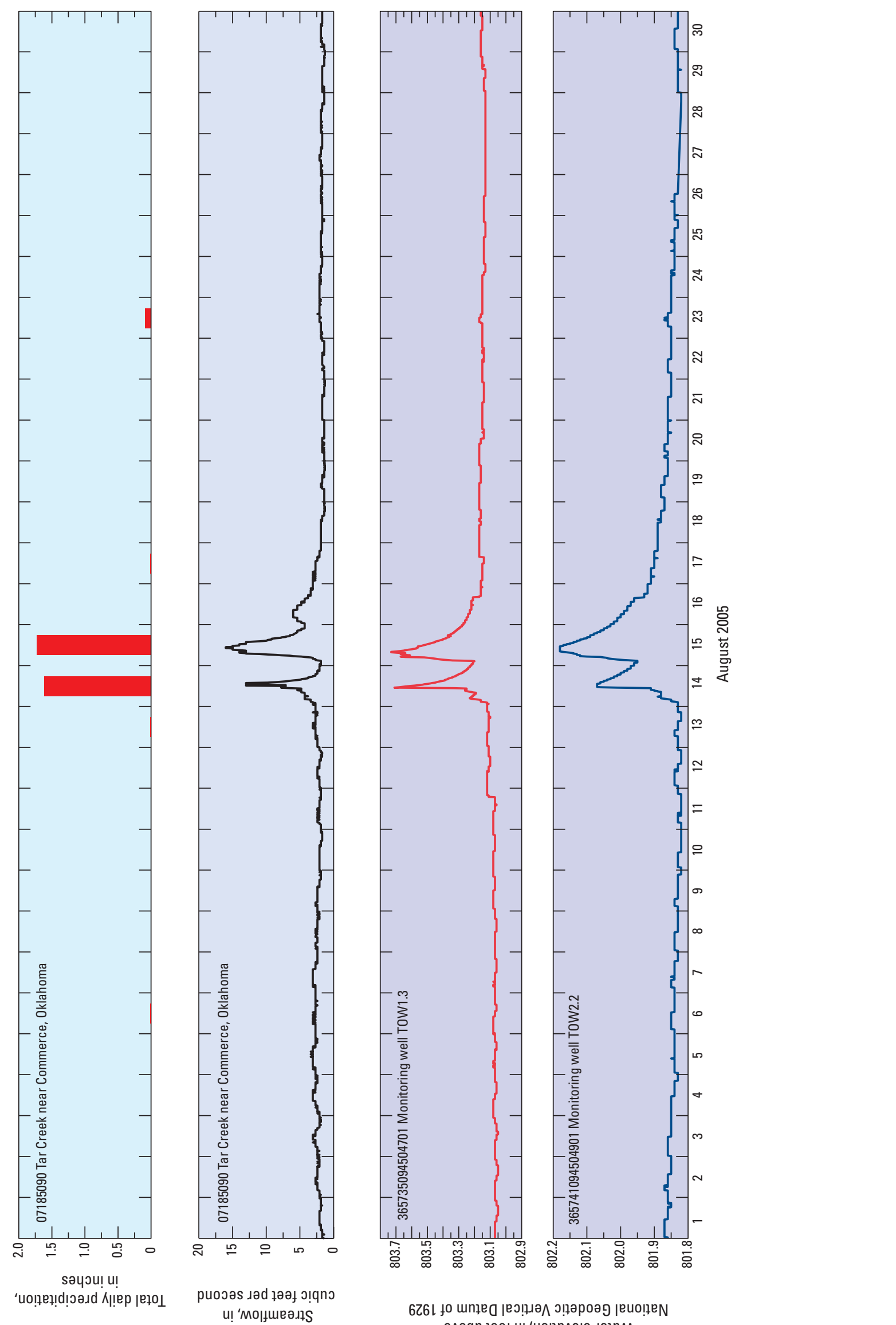

เั่

సิ

co

营

듬

. 
Table 2. Name and location of water-level monitoring wells in chat along Tar Creek in the Picher mining district, Ottawa County, Oklahoma.

[*, recorder wells; dec, decimal degrees]

\begin{tabular}{ccc}
\hline Well name & $\begin{array}{c}\text { Latitude } \\
\text { (dec) }\end{array}$ & $\begin{array}{c}\text { Longitude } \\
\text { (dec) }\end{array}$ \\
\hline TCE 1.1 & 36.94392 & 94.78561 \\
TCE 1.2 & 36.95989 & 94.84555 \\
TCE 1.3 & 36.95986 & 94.84558 \\
TCE 2.1 & 36.96145 & 94.84612 \\
TCE 2.2 & 36.96149 & 94.84623 \\
TCE 2.3 & 36.96150 & 94.84632 \\
TCW 1.1 & 36.95990 & 94.84624 \\
TCW 1.2 & 36.95981 & 94.84604 \\
TCW 1.3* & 36.95963 & 94.84595 \\
TCW 1.4 & 36.95971 & 94.84568 \\
TCW 1.5 & 36.95968 & 94.84577 \\
TCW 2.1 & 36.96125 & 94.84674 \\
TCW 2.2* & 36.96149 & 94.84664 \\
TCW 2.3 & 36.96153 & 94.84698 \\
TCW 2.4 & 36.96156 & 94.84646 \\
\hline
\end{tabular}

using water-quality samples and streamflow measurements at sites 071850825 and 071850870 , respectively (fig. 3).

Estimated metals loading to Tar Creek Study Segment from chat leachate was determined by subtracting loads from sites upstream from chat pile (Tar Creek site 071850825 and Lytle Creek site 071850870) from Tar Creek site 071850875 downstream from the chat pile (fig. 3). Estimated metals loading to Tar Creek Study Segment from mine outflow from old Lytle Creek above Douthat Bridge also was determined by subtracting loads in Tar Creek directly above the confluence with old Lytle Creek (site 071850875) from loads in Tar Creek directly below the confluence with old Lytle Creek

(site 07185088) (fig. 3).

Total cumulative loading estimates from chat leachate and mine outflow were calculated for the period beginning August 16 and ending August 30. Instantaneous loading values in pounds per day were interpolated throughout the 14-day period. Loading values calculated for samples and streamflow measurements collected August 16, 18, 20, 22, 24, and 29 were doubled to estimate cumulative loading values for August 17, 19, 21, 23, 25, and 30, when samples were not collected. Instantaneous loading value for August 26 was tripled to estimate cumulative loading on August 26-28.

\section{Quality Assurance/Quality Control}

An equipment blank for major ions and metals was collected for sampling equipment using metals-grade blank water prior to data collection (table 4). One sample of laboratory deionized water used for decontamination from all sources was sent for analysis of major ions and metals. In addition, a field blank and a duplicate sample were collected and analyzed for major ions and metals (table 4) (Wilde and Radtke, 1999).

\section{Streamflow, Water Quality, and Metal Loads from Chat Leachate and Mine Outflow}

All streamflow measurements and water-quality samples were collected following a rain event beginning on August 14, 2005. A total of about 3.3 inches of rainfall was recorded at USGS gaging station Tar Creek near Commerce (07185090) (fig. 1) on August 14-15 (fig. 5). Streamflow responded rapidly to rainfall over the study area and slowly declined to preevent conditions (fig. 5 and table 5). Rainfall readily infiltrated the unconsolidated chat and subsequently released leachate to Tar Creek. Streamflows generally declined over time following rainfall and ranged from less than 0.01 to $2.62 \mathrm{ft}^{3} / \mathrm{s}$ (table 5). Water-level elevations measured in wells installed 


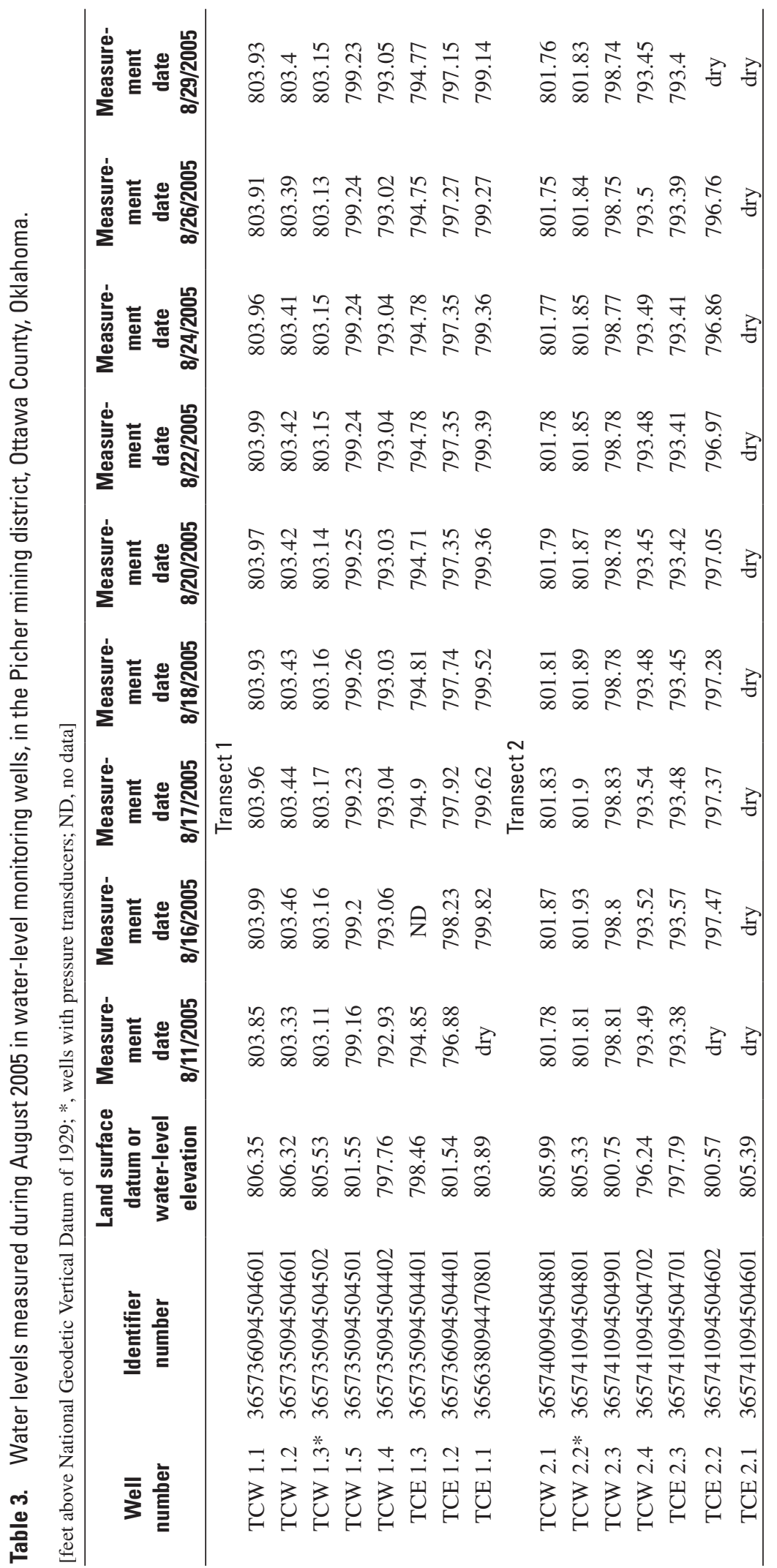




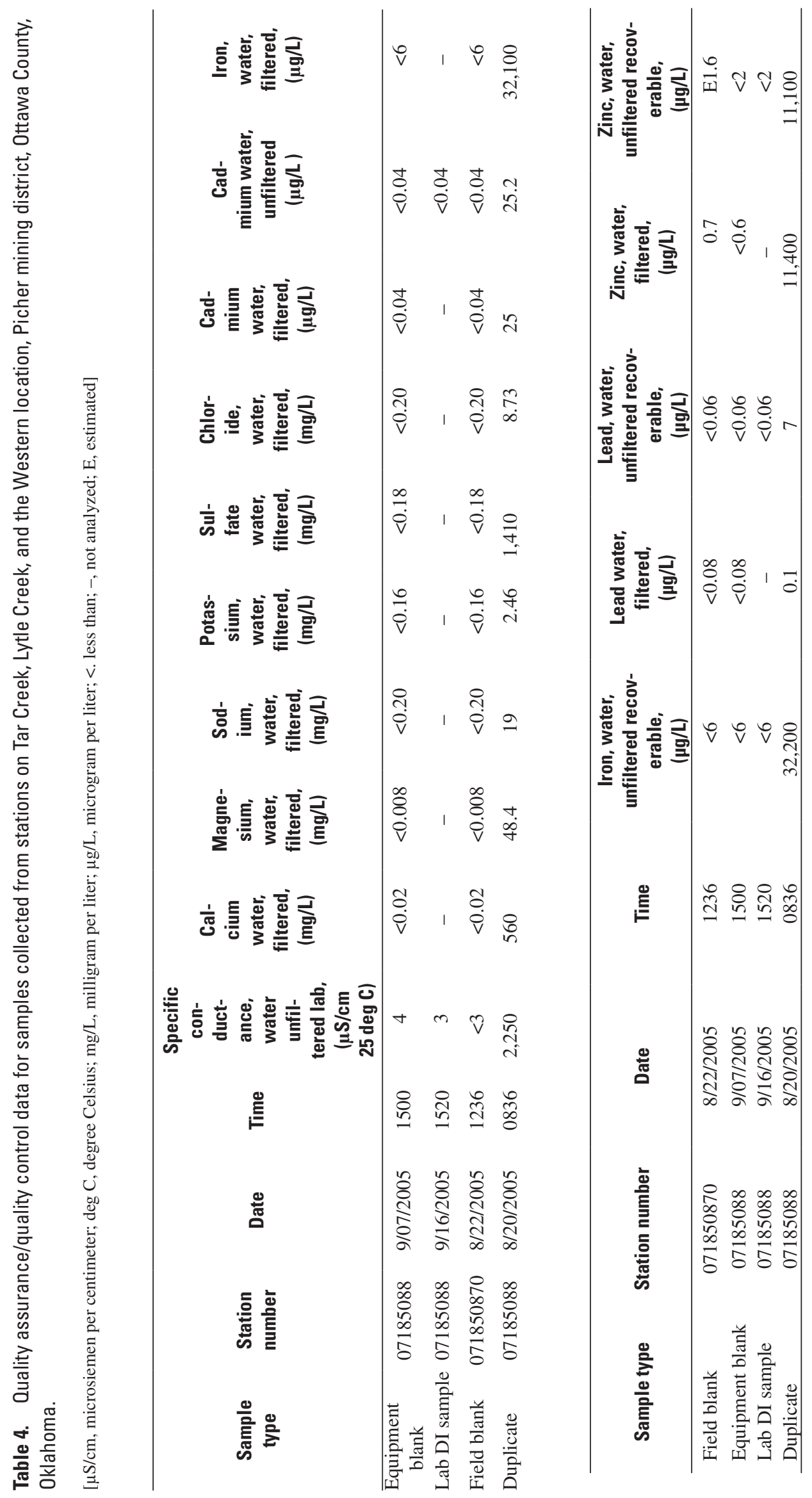


Table 5. Streamflow and water-quality data from stations on Tar Creek, Lytle Creek, and the Western location, Picher mining district, Ottawa County, Oklahoma.

[ft $\mathrm{ft}^{3} \mathrm{~s}$, cubic foot per second; unfiltered is total concentration and filtered is dissolved concentration for all constituents; $\mu \mathrm{S} / \mathrm{cm}$, microsiemen per centimeter; $<$, less than; LED, light emitting diode; FNU, formazin nephelometric unit; mg/L, milligram per liter; mV, millivolt; E, estimated; $\mu \mathrm{g} / \mathrm{L}$, microgram per liter; $\mathrm{mm}$, millimeter]

\begin{tabular}{|c|c|c|c|c|c|c|c|c|c|c|c|}
\hline $\begin{array}{c}\text { Station } \\
\text { name }\end{array}$ & Date & Time & $\begin{array}{c}\text { Stream- } \\
\text { flow, } \\
\left(\mathrm{ft}^{3} / \mathrm{s}\right)\end{array}$ & $\begin{array}{c}\text { Specific } \\
\text { conduc- } \\
\text { tance, } \\
\text { water } \\
\text { unfiltered } \\
\text { lab } \\
\text { ( } \mu \mathrm{S} / \mathrm{cm} \\
25 \text { degrees } \\
\text { Celsius) } \\
\end{array}$ & $\begin{array}{c}\text { Specific } \\
\text { conduc- } \\
\text { tance } \\
\text { water } \\
\text { unfiltered } \\
\text { field } \\
\text { ( } \mu \mathrm{S} / \mathrm{cm} \\
25 \text { degrees } \\
\text { Celsius) } \\
\end{array}$ & $\begin{array}{c}\text { pH, } \\
\text { water, } \\
\text { unfiltered } \\
\text { field } \\
\text { (standard } \\
\text { Units) }\end{array}$ & $\begin{array}{l}\text { Temper- } \\
\text { ature, } \\
\text { water } \\
\text { (degrees } \\
\text { Celsius) }\end{array}$ & $\begin{array}{l}\text { Turb- } \\
\text { idity, } \\
\text { infrared } \\
\text { LED } \\
\text { light, } \\
\text { detection } \\
\text { angle } \\
90 \text { degrees } \\
\text { (FNU) } \\
\end{array}$ & $\begin{array}{c}\text { Dis- } \\
\text { solved } \\
\text { oxygen } \\
\text { (mg/L) }\end{array}$ & $\begin{array}{c}\text { Oxi- } \\
\text { dation } \\
\text { re- } \\
\text { duction } \\
\text { poten- } \\
\text { tial, } \\
\text { (mV) }\end{array}$ & $\begin{array}{c}\text { Alka- } \\
\text { linity, } \\
\text { water } \\
\text { filtered } \\
\text { incremental } \\
\text { titration } \\
\text { field } \\
(\mathrm{mg} / \mathrm{L} \text { as } \\
\left.\mathrm{CaCO}_{3}\right) \\
\end{array}$ \\
\hline \multirow[t]{4}{*}{071850825} & $8 / 16 / 2005$ & 1350 & 0.06 & 919 & 947 & 7.2 & 25.3 & - & 7.2 & -38 & 138 \\
\hline & $8 / 18 / 2005$ & 1115 & 0.09 & 909 & 935 & 7.1 & 25 & 2.2 & 5.3 & -32 & 140 \\
\hline & $8 / 20 / 2005$ & 1130 & 0.04 & 935 & 944 & 7.1 & 25.6 & 2.5 & 5.3 & -77 & 142 \\
\hline & $8 / 22 / 2005$ & 1325 & 0.03 & 960 & 956 & 7 & 25 & 1.8 & 6.3 & -122 & 151 \\
\hline \multirow[t]{7}{*}{071850870} & $8 / 16 / 2005$ & 1415 & 1.58 & 1,780 & 1,820 & 6.7 & 29.6 & - & 7.8 & -17 & 58 \\
\hline & $8 / 18 / 2005$ & 1200 & 0.13 & 1,760 & 1,790 & 6.9 & 31.1 & 4 & 8.3 & -49 & 76 \\
\hline & $8 / 20 / 2005$ & 1030 & 0.04 & 1,820 & 1,830 & 7.1 & 29.1 & 1.5 & 7.8 & -40 & 100 \\
\hline & $8 / 22 / 2005$ & 1235 & 0.01 & 1,790 & 1,830 & 7.1 & 27.5 & 4.6 & 9 & -8 & 118 \\
\hline & $8 / 24 / 2005$ & 1215 & 0.02 & 1,780 & 1,820 & 7.2 & 32.5 & 1.7 & 9.8 & -31 & 113 \\
\hline & $8 / 26 / 2005$ & 1115 & $<0.01$ & 1,850 & 1,890 & 7.2 & 30.3 & 5 & 11.4 & -50 & 139 \\
\hline & $8 / 29 / 2005$ & 1200 & $<0.01$ & 1,980 & 2,000 & 6.9 & 28.6 & 1 & 11.4 & -93 & E146 \\
\hline 071850875 & $8 / 16 / 2005$ & 1125 & 1.62 & 1,850 & 1,880 & 6.9 & 26.6 & 3.1 & 8.5 & 17 & 72 \\
\hline \multirow[t]{7}{*}{07185088} & $8 / 16 / 2005$ & 1050 & 2.62 & 1,990 & 2,030 & 6.3 & 23.4 & 4.8 & 7.1 & 18 & 82 \\
\hline & $8 / 18 / 2005$ & 0813 & 1.3 & 2,120 & 2,200 & 6.2 & 21.8 & 7.6 & 6.8 & -21 & 103 \\
\hline & $8 / 20 / 2005$ & 0835 & 0.87 & 2,240 & 2,270 & 6 & 19.6 & 7.6 & 7.7 & -23 & 127 \\
\hline & $8 / 22 / 2005$ & 1045 & 0.94 & 2,230 & 2,310 & 6 & 19.4 & 7.4 & 10.1 & -52 & 114 \\
\hline & $8 / 24 / 2005$ & 1030 & 0.86 & 2,240 & 2,340 & 6 & 18.8 & 7.8 & 13.5 & -43 & 126 \\
\hline & $8 / 26 / 2005$ & 0930 & 0.78 & 2,280 & 2,380 & 6 & 18.9 & 5.9 & 18.8 & -27 & 131 \\
\hline & $8 / 29 / 2005$ & 1025 & 0.69 & 2,310 & 2,390 & 5.9 & 18.2 & 6.4 & 16.5 & -65 & 134 \\
\hline 071850818 & $8 / 16 / 2005$ & 1200 & $<0.01$ & 2,040 & 2,070 & 7.1 & 30.5 & - & 8.4 & - & 69 \\
\hline
\end{tabular}


Table 5. Streamflow and water-quality data from stations on Tar Creek, Lytle Creek, and the Western location, Picher mining district, Ottawa County, Oklahoma.-Continued

$\left[\mathrm{ft}^{3} / \mathrm{s}\right.$, cubic foot per second; unfiltered is total concentration and filtered is dissolved concentration for all constituents; $\mu \mathrm{S} / \mathrm{cm}$, microsiemen per centimeter; $<$, less than; LED, light emitting diode; FNU, formazin nephelometric unit; mg/L, milligram per liter; mV, millivolt; E, estimated; $\mu \mathrm{g} / \mathrm{L}$, microgram per liter; $\mathrm{mm}$, millimeter]

\begin{tabular}{|c|c|c|c|c|c|c|c|c|c|c|c|}
\hline $\begin{array}{c}\text { Station } \\
\text { name }\end{array}$ & Date & Time & $\begin{array}{c}\text { Calcium } \\
\text { water, } \\
\text { filtered } \\
(\mathrm{mg} / \mathrm{L})\end{array}$ & $\begin{array}{l}\text { Magnes- } \\
\text { ium, } \\
\text { water, } \\
\text { filtered } \\
\text { (mg/L) }\end{array}$ & $\begin{array}{c}\text { Sodium, } \\
\text { water, } \\
\text { filtered } \\
(\mathrm{mg} / \mathrm{L})\end{array}$ & $\begin{array}{l}\text { Potas- } \\
\text { sium, } \\
\text { water, } \\
\text { filtered } \\
\text { (mg/L) }\end{array}$ & $\begin{array}{c}\text { Bicar- } \\
\text { bonate, } \\
\text { water } \\
\text { filtered } \\
\text { incremental } \\
\text { titration } \\
\text { field, } \\
\text { (mg/L) }\end{array}$ & $\begin{array}{c}\text { Sulfate, } \\
\text { water, } \\
\text { filtered } \\
(\mathrm{mg} / \mathrm{L})\end{array}$ & $\begin{array}{c}\text { Chlor- } \\
\text { ide, } \\
\text { water, } \\
\text { filtered } \\
\text { (mg/L) }\end{array}$ & $\begin{array}{c}\text { Cadmium, } \\
\text { water, } \\
\text { filtered } \\
\text { ( } \mu \mathrm{g} / \mathrm{L} \text { ) }\end{array}$ & $\begin{array}{c}\text { Cadmium, } \\
\text { water, } \\
\text { unfiltered } \\
(\mu \mathrm{g} / \mathrm{L})\end{array}$ \\
\hline \multirow[t]{5}{*}{071850825} & $8 / 16 / 2005$ & 1350 & 169 & 17.4 & 13 & 2.34 & E166 & 335 & 14.4 & 7.09 & 7.68 \\
\hline & $8 / 18 / 2005$ & 1115 & 191 & 20.6 & 16.7 & 3.07 & 170 & 330 & 15.5 & 4.27 & 5.04 \\
\hline & $8 / 20 / 2005$ & 1130 & 181 & 17.6 & 14.2 & 2.52 & - & 343 & 14.9 & 3.32 & 4.28 \\
\hline & $8 / 22 / 2005$ & 1325 & 190 & 18.5 & 13.7 & 2.5 & 183 & 349 & 13.8 & 3 & 3.78 \\
\hline & $8 / 24 / 2005$ & 1310 & 172 & 18.5 & 13.2 & 2.54 & 185 & 344 & 13 & 2.91 & 4.27 \\
\hline \multirow[t]{7}{*}{071850870} & $8 / 16 / 2005$ & 1415 & 345 & 38.8 & 19.5 & 8.46 & E71 & 1,020 & 15.3 & 7.9 & 8.55 \\
\hline & $8 / 18 / 2005$ & 1200 & 357 & 37.7 & 21.6 & 7.01 & 93 & 986 & 16.6 & 2.09 & 2.07 \\
\hline & $8 / 20 / 2005$ & 1030 & 405 & 45.3 & 25.3 & 6.31 & 121 & 1010 & 17.5 & 1.26 & 1.13 \\
\hline & $8 / 22 / 2005$ & 1235 & 408 & 45.2 & 25.6 & 5.98 & 143 & 994 & 17.6 & 1.09 & 1.13 \\
\hline & $8 / 24 / 2005$ & 1215 & 372 & 45.6 & 26.1 & 5.55 & 136 & 969 & 17.1 & 0.7 & 0.83 \\
\hline & $8 / 26 / 2005$ & 1115 & 397 & 50 & 26.7 & 5.54 & 169 & 1,000 & 18.1 & 1.26 & 1.36 \\
\hline & $8 / 29 / 2005$ & 1200 & 442 & 52.4 & 29.1 & 5.05 & E178 & 1,090 & 20.1 & 2.3 & 3.61 \\
\hline \multirow[t]{2}{*}{071850875} & $8 / 16 / 2005$ & 1125 & 361 & 44 & 16.8 & 7.28 & 87 & 1,070 & 12.3 & 35 & 32.9 \\
\hline & $8 / 18 / 2005$ & 0950 & 382 & 52.2 & 15.8 & 4.08 & 128 & 1,070 & 10.8 & 48.8 & 43.8 \\
\hline & $8 / 18 / 2005$ & 0813 & 482 & 48.1 & 18.9 & 3.28 & 125 & 1,310 & 10.1 & 27.7 & 25.4 \\
\hline & $8 / 20 / 2005$ & 0835 & 558 & 48.6 & 19 & 2.51 & 155 & 1,410 & 8.77 & 25.2 & 25 \\
\hline & $8 / 22 / 2005$ & 1045 & 528 & 50.5 & 19.2 & 2.56 & 139 & 1,400 & 8.5 & 25.5 & 24.8 \\
\hline & $8 / 24 / 2005$ & 1030 & 525 & 50.5 & 19 & 2.45 & 154 & 1,420 & 8.56 & 24.2 & 24.2 \\
\hline & $8 / 26 / 2005$ & 0930 & 542 & 51.4 & 18.2 & 2.35 & 160 & 1,420 & 8.52 & 23.9 & 24.2 \\
\hline & $8 / 29 / 2005$ & 1025 & 557 & 49.7 & 18.9 & 2.39 & 163 & 1,450 & 8.7 & 17 & 18.2 \\
\hline 071850818 & $8 / 16 / 2005$ & 1200 & 554 & 16.2 & 2.35 & 1.24 & 83 & 1,260 & $<1.00$ & 103 & 95.3 \\
\hline
\end{tabular}


Table 5. Streamflow and water-quality data from stations on Tar Creek, Lytle Creek, and the Western location, Picher mining district, Ottawa County, Oklahoma.-Continued

$\left[\mathrm{ft}^{3} / \mathrm{s}\right.$, cubic foot per second; unfiltered is total concentration and filtered is dissolved concentration for all constituents; $\mu \mathrm{S} / \mathrm{cm}$, microsiemen per centimeter; $<$, less than; LED, light emitting diode; FNU, formazin nephelometric unit; mg/L, milligram per liter; mV, millivolt; E, estimated; $\mu \mathrm{g} / \mathrm{L}$, microgram per liter; mm, millimeter]

\begin{tabular}{|c|c|c|c|c|c|c|c|c|c|c|}
\hline $\begin{array}{c}\text { Station } \\
\text { name }\end{array}$ & Date & Time & $\begin{array}{c}\text { Iron, } \\
\text { water, } \\
\text { filtered } \\
(\mu \mathrm{g} / \mathrm{L})\end{array}$ & $\begin{array}{c}\text { Iron, } \\
\text { water, } \\
\text { unfiltered } \\
\text { recover- } \\
\text { able } \\
\text { ( } \mu \mathrm{g} / \mathrm{L})\end{array}$ & $\begin{array}{c}\text { Lead, } \\
\text { water, } \\
\text { filtered } \\
\text { ( } \mathrm{gg} / \mathrm{L} \text { ) }\end{array}$ & $\begin{array}{l}\text { Lead, } \\
\text { water, } \\
\text { unfiltered } \\
\text { recover- } \\
\text { able } \\
\text { ( } \mu \mathrm{g} / \mathrm{L})\end{array}$ & $\begin{array}{c}\text { Zinc, } \\
\text { water, } \\
\text { filtered } \\
(\mu \mathrm{g} / \mathrm{L})\end{array}$ & $\begin{array}{c}\text { Zinc, } \\
\text { water, } \\
\text { unfiltered } \\
\text { recover- } \\
\text { able } \\
(\mu \mathrm{g} / \mathrm{L})\end{array}$ & $\begin{array}{c}\text { Suspended } \\
\text { sedi- } \\
\text { ment, } \\
\text { sieve } \\
\text { diameter } \\
\text { percent } \\
\text { (<.063mm) }\end{array}$ & $\begin{array}{c}\text { Sus- } \\
\text { pended } \\
\text { Sedi- } \\
\text { ment, } \\
\text { concen- } \\
\text { tration } \\
\text { (mg/L) }\end{array}$ \\
\hline \multirow{5}{*}{071850825} & $8 / 18 / 2005$ & 1115 & 11 & 509 & 0.21 & 6.5 & 3,330 & 3,510 & 50 & 3 \\
\hline & $8 / 20 / 2005$ & 1130 & 86 & 645 & 0.21 & 8.5 & 3,210 & 3,140 & 67 & 3 \\
\hline & $8 / 22 / 2005$ & 1325 & 116 & 676 & 0.34 & 10.4 & 3,050 & 3,120 & 83 & 5 \\
\hline & $8 / 24 / 2005$ & 1310 & 86 & 821 & 0.23 & 26.7 & 2,800 & 3,420 & 60 & 12 \\
\hline & $8 / 26 / 2005$ & 1145 & 145 & 727 & 0.16 & 8 & 2,700 & 2,750 & 50 & 6 \\
\hline \multirow{6}{*}{071850870} & $8 / 18 / 2005$ & 1200 & 762 & 1,560 & E0.04 & 0.8 & 17,300 & 17,700 & 75 & 12 \\
\hline & $8 / 20 / 2005$ & 1030 & $<6$ & 441 & 0.14 & 0.5 & 4,530 & 4,430 & 54 & 4 \\
\hline & $8 / 22 / 2005$ & 1235 & E3 & 689 & 0.1 & 1.8 & 3,080 & 3,100 & 75 & 9 \\
\hline & $8 / 24 / 2005$ & 1215 & 8 & 458 & E0.07 & 1.6 & 1,620 & 1,670 & 57 & 6 \\
\hline & $8 / 26 / 2005$ & 1115 & 8 & 170 & 0.25 & 0.8 & 2,360 & 2,260 & 71 & 4 \\
\hline & $8 / 29 / 2005$ & 1200 & E6 & 3,690 & 0.23 & 17.4 & 3,580 & 4,380 & 59 & 94 \\
\hline \multirow[t]{3}{*}{071850875} & $8 / 16 / 2005$ & 1125 & 49 & 626 & 1.88 & 14.5 & 61,700 & 59,800 & 60 & 32 \\
\hline & $8 / 18 / 2005$ & 0950 & 40 & 350 & 0.64 & 3.9 & 23,700 & 22,100 & 31 & 10 \\
\hline & $8 / 20 / 2005$ & 0905 & 92 & 656 & 0.89 & 11.1 & 22,000 & 19,800 & 29 & 22 \\
\hline \multirow{6}{*}{07185088} & $8 / 18 / 2005$ & 0813 & 24,600 & 26,200 & 0.17 & 4.3 & 14,800 & 13,900 & 97 & 63 \\
\hline & $8 / 20 / 2005$ & 0835 & 32,200 & 33,200 & 0.15 & 7 & 11,500 & 10,900 & 96 & 76 \\
\hline & $8 / 22 / 2005$ & 1045 & 31,200 & 30,200 & 0.17 & 3.8 & 10,400 & 11,600 & 98 & 67 \\
\hline & $8 / 24 / 2005$ & 1030 & 32,100 & 32,200 & 0.14 & 3.9 & 10,100 & 10,900 & 96 & 77 \\
\hline & $8 / 26 / 2005$ & 0930 & 33,600 & 33,200 & 0.23 & 3.1 & 10,300 & 9,830 & 95 & 76 \\
\hline & $8 / 29 / 2005$ & 1025 & 37,500 & 38,000 & 0.16 & 3.2 & 9,070 & 8,950 & 99 & 72 \\
\hline 071850818 & $8 / 16 / 2005$ & 1200 & 47 & 182 & 117 & 170 & 1,730 & 1,760 & 26 & 5 \\
\hline
\end{tabular}


in the chat (table 3 and fig. 5) show general rise and decline as water moves through chat to the streams. Water-level elevations also show that gradient of flow is from chat to the streams (table 3).

\section{Streamflow}

Only one streamflow measurement was collected August 16 from runoff at the Western location (site 071850818) (table 5). Measured streamflow on August 16 was less than $0.01 \mathrm{ft}^{3} / \mathrm{s}$, with streamflows after that date diminishing to levels too small to be measured.

Seven streamflow measurements were made at each site in Tar Creek Study Segment during sampling (table 5). Streamflow measurements were made on August 16, 18, 20, 22, 24, 26, and 29. No streamflow measurements were made in Tar Creek Study Segment after August 29 as streamflow values and water levels had returned to pre-rain event levels. Measured streamflow within Tar Creek Study Segment ranged from less than 0.01 to $2.62 \mathrm{ft}^{3} / \mathrm{s}$.

\section{Water Quality}

One water-quality sample was collected August 16 from runoff at the Western location (site 071850818) (table 5). Seven water-quality samples were collected at each of the four sites in Tar Creek Study Segment (table 5). Samples were collected on August 16, 18, 20, 22, 24, 26, and 29. No waterquality samples were collected in Tar Creek Study Segment after August 29 as streamflow values and water levels had returned to pre-rain event levels.

Field measurements collected at the Western location (site 071850818) were as follows: Specific conductance 2,070 microsiemens per centimeter at $25^{\circ}$ Celsius $(\mu \mathrm{S} / \mathrm{cm}), \mathrm{pH}$ 7.1 standard units, temperature $30.5^{\circ}$ Celsius, dissolved oxygen $8.4 \mathrm{mg} / \mathrm{L}$, and alkalinity $69 \mathrm{mg} / \mathrm{L}$ (table 5). No turbidity or oxidation-reduction potential readings were collected at this site due to equipment malfunction.

Field measurements of specific conductance at Tar Creek Study Segment ranged from 935 to $2,390 \mu \mathrm{S} / \mathrm{cm}$ with a mean of $1,750 \mu \mathrm{S} / \mathrm{cm}$ (table 5 ). The $\mathrm{pH}$ ranged from 5.9 to 7.2 standard units, with a mean of 6.8 standard units. Temperature ranged from 18.2 to $32.5^{\circ}$ Celsius with a mean of $25.4^{\circ}$ Celsius. Alkalinity ranged from 58 to $165 \mathrm{mg} / \mathrm{L}$ with a mean of $118 \mathrm{mg} / \mathrm{L}$. Turbidity ranged from 1 to 7.8 formazin nephelometric units, (fnu), with a mean of $3.3 \mathrm{fnu}$. Dissolved oxygen ranged from 5.3 to $18.8 \mathrm{mg} / \mathrm{L}$ with a mean of $9.6 \mathrm{mg} / \mathrm{L}$. Oxidation-reduction potential ranged from -122 to 18 millivolts $(\mathrm{mV})$ with a mean of $-41 \mathrm{mV}$.

Metals, with the exception of iron, at the Western location generally were predominate in the dissolved phase (table 5). Total cadmium concentration of the sample collected at the Western location (site 071850818) was 95.3 micrograms per liter $(\mu \mathrm{g} / \mathrm{L})$ and dissolved cadmium concentration was $103 \mu \mathrm{g} / \mathrm{L}$. A dissolved cadmium concentration greater than the total cadmium concentration can be the result of the analytical or sampling process. Total iron concentration was $182 \mu \mathrm{g} / \mathrm{L}$, while dissolved iron concentration was $47 \mu \mathrm{g} / \mathrm{L}$. Total and dissolved lead concentrations were 170 and $117 \mu \mathrm{g} / \mathrm{L}$, respectively. Total zinc concentration was $1,760 \mu \mathrm{g} / \mathrm{L}$ and dissolved zinc concentration was $1,730 \mu \mathrm{g} / \mathrm{L}$.

Cadmium and zinc at Tar Creek Study Segment generally were predominate in the dissolved phase, while total iron and lead generally were predominate (table 5). Total cadmium concentrations of samples collected from Tar Creek Study Segment ranged from 0.83 to $62 \mu \mathrm{g} / \mathrm{L}$ with a mean of $21.18 \mu \mathrm{g} / \mathrm{L}$ (table 5). Total iron concentrations ranged from 170 to $38,000 \mu \mathrm{g} / \mathrm{L}$ with a mean of $7,924 \mu \mathrm{g} / \mathrm{L}$. Total lead concentrations ranged from 0.50 to $26.7 \mu \mathrm{g} / \mathrm{L}$ with a mean of $7.68 \mu \mathrm{g} / \mathrm{L}$. Total zinc concentrations ranged from 1,670 to $59,900 \mu \mathrm{g} / \mathrm{L}$ with a mean of $14,548 \mu \mathrm{g} / \mathrm{L}$.

\section{Metal Loads from Chat Leachate and Mine Outflow}

No loading values were calculated for the Western location (site 071850818$)$. The low streamflow value $\left(<0.01 \mathrm{ft}^{3} / \mathrm{s}\right)$ indicates that during the sampling period metal load contributions would have been negligible.

Instantaneous loads, in pounds per day, were calculated for cadmium, iron, lead, and zinc at each of the four sampling sites in Tar Creek Study Segment (table 6). Instantaneous loads generally decreased following the first day of sampling.

Total cadmium loading values from Tar Creek near Cardin, Okla. (site 071850825 ) ranged from $<0.001$ to $0.002 \mathrm{lb} /$ day. Total iron loading values ranged from 0.071 to $0.247 \mathrm{lb} /$ day with a mean of $0.132 \mathrm{lb} /$ day. Total lead loading values ranged from $<0.001$ to $0.003 \mathrm{lb} /$ day. Total zinc loading values ranged from 0.262 to $1.70 \mathrm{lb} /$ day with a mean of $0.743 \mathrm{lb} /$ day (table 6).

Total cadmium loading values from Lytle Creek near Cardin, Okla. (site 071850870) ranged from $<0.001$ to $0.073 \mathrm{lb} /$ day. Total iron loading values ranged from $<0.001$ to $9.37 \mathrm{lb} /$ day. Total lead loading values ranged from $<0.001$ to $0.088 \mathrm{lb} /$ day. Total zinc loading values ranged from E0.047 to $510 \mathrm{lb} /$ day (table 6).

Total cadmium loading values from Tar Creek above Douthat Bridge (site 071850875) ranged from 0.062 to $0.287 \mathrm{lb} /$ day with a mean of $0.115 \mathrm{lb} /$ day. Total iron loading values ranged from 0.432 to $5.47 \mathrm{lb} /$ day with a mean of $1.48 \mathrm{lb} /$ day. Total lead loading values ranged from 0.004 to $0.127 \mathrm{lb} /$ day with a mean of $0.029 \mathrm{lb} /$ day. Total zinc loading values ranged from 20.1 to $522 \mathrm{lb} /$ day with a mean of $102 \mathrm{lb} /$ day (table 6).

Total cadmium loading values from Tar Creek near Picher, Okla. (site 07185088) ranged from 0.068 to $0.391 \mathrm{lb} /$ day with a mean of $0.156 \mathrm{lb} /$ day. Total iron loading values ranged from 140 to $184 \mathrm{lb} /$ day with a mean of $157 \mathrm{lb} /$ day. Total lead loading values ranged from 0.012 to $0.151 \mathrm{lb} /$ day with a mean of $0.039 \mathrm{lb} /$ day. Total zinc loading 
Table 6. Calculated total and dissolved instantaneous metal loads from Tar Creek Study Segment in Ottawa County, Oklahoma.

[lb/day, pound per day; <, less than; all values smaller than 0.001 are presented as $<0.001$; and actual values are used in summary statistics; - , value not calculated; E, estimated load due to estimated discharge]

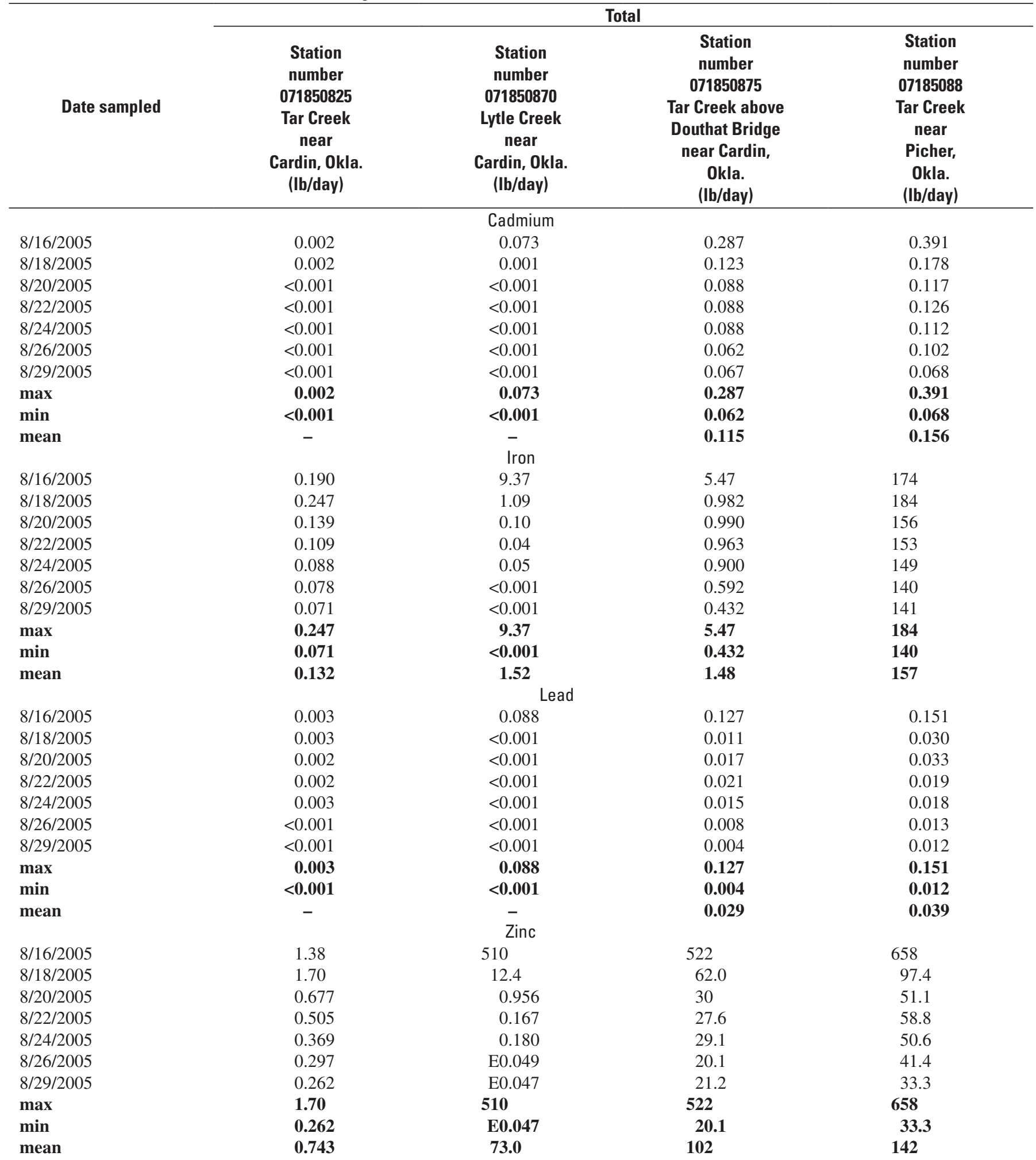


Table 6. Calculated total and dissolved instantaneous metal loads from Tar Creek Study Segment in Ottawa County, Oklahoma.Continued

[lb/day, pound per day; $<$, less than; all values smaller than 0.001 are presented as $<0.001$; and actual values are used in summary statistics; - , value not calculated; E, estimated load due to estimated discharge]

\begin{tabular}{|c|c|c|c|c|}
\hline \multirow[b]{2}{*}{ Date sampled } & \multicolumn{4}{|c|}{ Dissolved } \\
\hline & $\begin{array}{c}\text { Station } \\
\text { number } \\
\mathbf{0 7 1 8 5 0 8 2 5} \\
\text { Tar Creek } \\
\text { near } \\
\text { Cardin, Okla. } \\
\text { (Ib/day) }\end{array}$ & $\begin{array}{c}\text { Station } \\
\text { number } \\
071850870 \\
\text { Lytle Creek } \\
\text { near } \\
\text { Cardin, Okla. } \\
\text { (lb/day) }\end{array}$ & $\begin{array}{c}\text { Station } \\
\text { number } \\
071850875 \\
\text { Tar Creek above } \\
\text { Douthat Bridge } \\
\text { near Cardin, } \\
\text { Okla. } \\
\text { (Ib/day) }\end{array}$ & $\begin{array}{c}\text { Station } \\
\text { number } \\
\text { 07185088 } \\
\text { Tar Creek } \\
\text { near } \\
\text { Picher, } \\
\text { Okla. } \\
\text { (Ib/day) }\end{array}$ \\
\hline \multicolumn{5}{|c|}{ Cadmium } \\
\hline $8 / 16 / 2005$ & 0.002 & 0.067 & 0.306 & 0.401 \\
\hline $8 / 18 / 2005$ & 0.002 & 0.001 & 0.137 & 0.194 \\
\hline $8 / 20 / 2005$ & $<0.001$ & $<0.001$ & 0.092 & 0.118 \\
\hline $8 / 22 / 2005$ & $<0.001$ & $<0.001$ & 0.090 & 0.129 \\
\hline $\min$ & $<0.001$ & $<0.001$ & 0.062 & 0.063 \\
\hline \multicolumn{5}{|c|}{ Iron } \\
\hline $8 / 16 / 2005$ & 0.016 & 2.56 & 0.428 & 161 \\
\hline $8 / 18 / 2005$ & 0.005 & 0.534 & 0.112 & 172 \\
\hline $8 / 20 / 2005$ & 0.018 & $<0.001$ & 0.139 & 151 \\
\hline $8 / 22 / 2005$ & 0.019 & $<0.001$ & 0.113 & 158 \\
\hline $8 / 24 / 2005$ & 0.009 & $<0.001$ & 0.065 & 149 \\
\hline $8 / 26 / 2005$ & 0.016 & $<0.001$ & 0.070 & 141 \\
\hline $8 / 29 / 2005$ & 0.011 & $<0.001$ & 0.079 & 140 \\
\hline $\max$ & 0.019 & 2.56 & 0.428 & 172 \\
\hline $\min$ & 0.005 & $<0.001$ & 0.065 & 140 \\
\hline $8 / 26 / 2005$ & $<0.001$ & $<0.001$ & 0.001 & $<0.001$ \\
\hline $8 / 29 / 2005$ & $<0.001$ & $<0.001$ & $<0.001$ & $<0.001$ \\
\hline $\max$ & $<0.001$ & 0.005 & 0.016 & 0.008 \\
\hline $\min$ & $<0.001$ & $<0.001$ & $<0.001$ & $<0.001$ \\
\hline \multicolumn{5}{|c|}{ Zinc } \\
\hline $8 / 16 / 2005$ & 1.35 & 510 & 539 & 613 \\
\hline $8 / 18 / 2005$ & 1.62 & 12.1 & 66.5 & 104 \\
\hline $8 / 20 / 2005$ & 0.692 & 0.977 & 33.2 & 54.0 \\
\hline $8 / 22 / 2005$ & 0.493 & 0.175 & 30.8 & 52.7 \\
\hline $8 / 24 / 2005$ & 0.302 & 0.131 & 26.9 & 46.8 \\
\hline $8 / 26 / 2005$ & 0.291 & E0.051 & 19.7 & 43.3 \\
\hline $8 / 29 / 2005$ & 0.256 & E0.039 & 21.4 & 33.8 \\
\hline $\max$ & 1.62 & 510 & 539 & 613 \\
\hline $\min$ & 0.256 & E0.039 & 19.7 & 33.8 \\
\hline mean & 0.714 & 74.9 & 105 & 135 \\
\hline
\end{tabular}


values ranged from 33.3 to $658 \mathrm{lb} /$ day with a mean of $142 \mathrm{lb} /$ day (table 6).

Metals loading to Tar Creek Study Segment from chat leachate were estimated by subtracting loads upstream of the chat pile from loads downstream of the chat pile (fig. 3 and table 7). Total cadmium loading from chat leachate ranged from 0.062 to $0.212 \mathrm{lb} /$ day with a mean of $0.104 \mathrm{lb} /$ day. Total iron loading from chat leachate ranged from $<0.001$ to $0.814 \mathrm{lb} /$ day. Total lead loading from chat leachate ranged from 0.003 to $0.036 \mathrm{lb} /$ day with a mean of $0.014 \mathrm{lb} /$ day. Total zinc loading from chat leachate ranged from 10.6 to $47.9 \mathrm{lb} /$ day with a mean of $26.2 \mathrm{lb} /$ day (table 7).

Metals loading to Tar Creek Study Segment from mine outflow were estimated by subtracting loads above the confluence with old Lytle Creek from loads below the confluence with old Lytle Creek (fig. 3 and table 7). Total cadmium loading from mine outflow ranged from 0.001 to

$0.104 \mathrm{lb} /$ day with a mean of $0.042 \mathrm{lb} / \mathrm{day}$. Total iron loading from mine outflow ranged from 139 to $183 \mathrm{lb}$ /day with a mean of $155 \mathrm{lb}$ /day. Total lead loading from mine outflow ranged from $<0.001$ to $0.024 \mathrm{lb} /$ day. Total zinc loading from mine outflow ranged from 12.1 to $136 \mathrm{lb} /$ day with a mean of $39.8 \mathrm{lb} /$ day (table 7).

Total metal loads for Tar Creek Study Segment were estimated for the period beginning August 16 and ending August 30 and the percentage from each source calculated (table 8). Four sources of calculated metal loads are from Tar Creek and Lytle Creek entering the study segment, from chat pile leachate, and from mine outflow from old Lytle Creek. About 68 percent of total and dissolved cadmium was from chat leachate and about 26 percent was from mine outflow. About 99 percent of total and dissolved iron loading was from mine outflow. About 51 percent of total lead loading was from chat leachate, about 21 percent from mine drainage, and about 24 percent from Lytle Creek, while about 77 percent of dissolved lead loading was from chat leachate and about 23 percent from Lytle Creek. About 19 percent of total zinc loading was from chat leachate, about 29 percent from mine outflow, and about 52 percent from Lytle Creek (table 8).

An estimate of the metals loading from chat within Tar Creek watershed, which includes Lytle Creek, can be made from loads measured at Tar Creek above Douthat Bridge (071850875). This estimate would be limited to conditions of the study, but would provide an estimated range of daily loading. Prior to chat leachate sampling there was no measurable velocity in Tar Creek at the Kansas/Oklahoma state line. Streamflow measured at Lytle Creek approximately 200 yards south of the state line was less than $0.01 \mathrm{ft}^{3} / \mathrm{s}$. Therefore, all base flow is presumed to come from chat leachate from state line to the sampling site at Tar Creek. Estimated base flow loading from chat leachate into Tar Creek Study Segment from state line to Tar Creek above Douthat Bridge (071850875) contained substantial amounts of zinc. Estimated median total zinc load was $29.1 \mathrm{lb}$ /day. Iron was next highest metal load with estimated median total iron load of $0.970 \mathrm{lb} /$ day (table 9).

\section{Summary}

Picher mining district is an abandoned lead and zinc mining area located in Ottawa County, northeastern Oklahoma. During the first half of the 20th century, the area was a primary producer of lead and zinc in the United States. These minerals were found in the sulfide minerals of Mississippianage Boone Formation. Ore production in Picher mining district was active from about 1900 until the mid-1970s. Production reached a peak by 1925 with 387,000 tons of recoverable zinc and 101,000 tons of recoverable lead being produced. The mines maintained moderate production levels until the 1950s when yields began to decline.

Large accumulations of gravel- to sand-sized mine tailings, locally referred to as chat, are present throughout the mining area. Ponds of silt- and clay-sized byproducts of the gravity separation process, referred to as mill pond wastes, are generally located adjacent to chat piles. Chat and mill pond wastes contain trace amounts of metals associated with lead and zinc sulfide ores. Leachate from chat and mill pond wastes discharges to drainage areas within the mining area. Mine outflow occurs from several locations in the mining area, from unplugged mine shafts, vent holes, seeps, and abandoned mine dewatering wells. Metals from mine outflow can be a substantial contribution to total metal loading to streams. Information about the amount of metal loading from chat and mine outflow is needed. U.S. Geological Survey in cooperation with Environment Protection Agency, began a study in 2005 to collect water-quality data, characterize flow, and calculate loads of selected metals entering Tar Creek.

Two locations were selected for surface-water sampling: Western location, (29N-23E-19), west of the town of Cardin, and Tar Creek Study Segment, (29N-23E-29 and 32). The Western location contains one sampling site, (071850818). This site is located at a discharge point where a berm around a mill pond has been breached and incised by previous runoff.

Tar Creek Study Segment is a reach of Tar Creek that passes through chat piles from above the confluence with Lytle Creek to Douthat bridge. Tar Creek Study Segment contains four sampling sites, (071850825, 071850870, 071850875, and 07185088). A substantial amount of mine outflow enters Tar Creek just above Douthat bridge from the old Lytle Creek channel. Samples collected at Tar Creek near Picher, Okla., (07185088), represent both leachate from chat piles and mine outflow.

Streamflow measurements and water-quality samples were collected following a rain event August 2005. Samples were analyzed for water properties, dissolved major ions (calcium, magnesium, sodium, potassium, and sulfate), total metals (cadmium, iron, lead, and zinc), and dissolved metals (cadmium, iron, lead, and zinc). Suspended sediment also was analyzed.

Water properties analyzed were: specific conductance, $\mathrm{pH}$, temperature, turbidity, dissolved oxygen, oxidation-reduction potential, and alkalinity. 
Table 7. Calculated total and dissolved metal loads from chat leachate and mine outflow to Tar Creek in the Picher mining district in Ottawa County Oklahoma.

[lb/day, pound per day; <, less than]

\begin{tabular}{|c|c|c|c|c|}
\hline \multirow{2}{*}{$\begin{array}{c}\text { Date } \\
\text { sampled }\end{array}$} & \multicolumn{2}{|c|}{ Total } & \multicolumn{2}{|c|}{ Dissolved } \\
\hline & $\begin{array}{c}\text { Leachate load } \\
\text { (lb/day) }\end{array}$ & $\begin{array}{c}\text { Mine outflow load } \\
\text { (Ib/day) }\end{array}$ & $\begin{array}{c}\text { Leachate load } \\
\text { (Ib/day) }\end{array}$ & $\begin{array}{c}\text { Mine outflow load } \\
\text { (Ib/day) }\end{array}$ \\
\hline & \multicolumn{4}{|c|}{ Cadmium } \\
\hline $8 / 16 / 2005$ & 0.212 & 0.104 & 0.237 & 0.095 \\
\hline $8 / 18 / 2005$ & 0.120 & 0.055 & 0.134 & 0.057 \\
\hline $8 / 20 / 2005$ & 0.088 & 0.029 & 0.092 & 0.026 \\
\hline $8 / 22 / 2005$ & 0.088 & 0.038 & 0.090 & 0.039 \\
\hline $8 / 24 / 2005$ & 0.088 & 0.024 & 0.090 & 0.022 \\
\hline $8 / 26 / 2005$ & 0.062 & 0.040 & 0.062 & 0.038 \\
\hline $8 / 29 / 2005$ & 0.067 & 0.001 & 0.063 & 0 \\
\hline $\max$ & 0.212 & 0.104 & 0.237 & 0.095 \\
\hline $\min$ & 0.002 & 0.001 & 0.062 & $\mathbf{0}$ \\
\hline \multirow[t]{2}{*}{ mean } & 0.104 & 0.042 & 0.110 & 0.040 \\
\hline & \multicolumn{4}{|c|}{ Iron } \\
\hline $8 / 16 / 2005$ & $<0.001$ & 168 & $<.001$ & 160 \\
\hline $8 / 18 / 2005$ & $<0.001$ & 183 & $<.001$ & 172 \\
\hline $8 / 20 / 2005$ & 0.751 & 155 & 0.121 & 151 \\
\hline $8 / 22 / 2005$ & 0.814 & 152 & 0.094 & 158 \\
\hline $8 / 24 / 2005$ & 0.762 & 148 & 0.056 & 149 \\
\hline $8 / 26 / 2005$ & 0.514 & 139 & 0.054 & 141 \\
\hline $8 / 29 / 2005$ & 0.361 & 140 & 0.068 & 140 \\
\hline $\max$ & 0.814 & 183 & 0.121 & 172 \\
\hline $\min$ & $<0.001$ & 139 & $<0.001$ & 140 \\
\hline \multirow[t]{2}{*}{ mean } & 0.457 & 155 & - & 153 \\
\hline & \multicolumn{4}{|c|}{ Lead } \\
\hline $8 / 16 / 2005$ & 0.036 & 0.024 & 0.011 & $<.001$ \\
\hline $8 / 18 / 2005$ & 0.008 & 0.019 & 0.002 & $<.001$ \\
\hline $8 / 20 / 2005$ & 0.015 & 0.016 & 0.001 & $<.001$ \\
\hline $8 / 22 / 2005$ & 0.019 & $<0.001$ & 0.001 & $<.001$ \\
\hline $8 / 24 / 2005$ & 0.012 & 0.003 & $<.001$ & $<.001$ \\
\hline $8 / 26 / 2005$ & 0.008 & 0.005 & 0.001 & $<.001$ \\
\hline $8 / 29 / 2005$ & 0.003 & 0.008 & $<.001$ & $<.001$ \\
\hline $\max$ & 0.036 & 0.024 & 0.011 & $<.001$ \\
\hline $\min$ & 0.003 & $<0.001$ & $<.001$ & $<.001$ \\
\hline \multirow[t]{2}{*}{ mean } & 0.014 & - & - & $<.001$ \\
\hline & \multicolumn{4}{|c|}{ Zinc } \\
\hline $8 / 16 / 2005$ & 10.6 & 136 & 27.6 & 74.0 \\
\hline $8 / 18 / 2005$ & 47.9 & 35.4 & 52.8 & 37.5 \\
\hline $8 / 20 / 2005$ & 28.4 & 21.1 & 31.5 & 20.8 \\
\hline $8 / 22 / 2005$ & 26.9 & 31.2 & 30.1 & 21.9 \\
\hline $8 / 24 / 2005$ & 28.6 & 21.5 & 26.4 & 19.9 \\
\hline $8 / 26 / 2005$ & 19.8 & 21.3 & 19.4 & 23.6 \\
\hline $8 / 29 / 2005$ & 20.9 & 12.1 & 21.1 & 12.4 \\
\hline $\max$ & 47.9 & 136 & 52.8 & 74.0 \\
\hline $\min$ & 10.6 & 12.1 & 19.4 & 12.4 \\
\hline mean & 26.2 & 39.8 & 29.9 & 30 \\
\hline
\end{tabular}


Table 8. Total estimated metal load for the 14-day sampling period and percentage from source for the Tar Creek Study Segment, Ottawa County, Oklahoma.

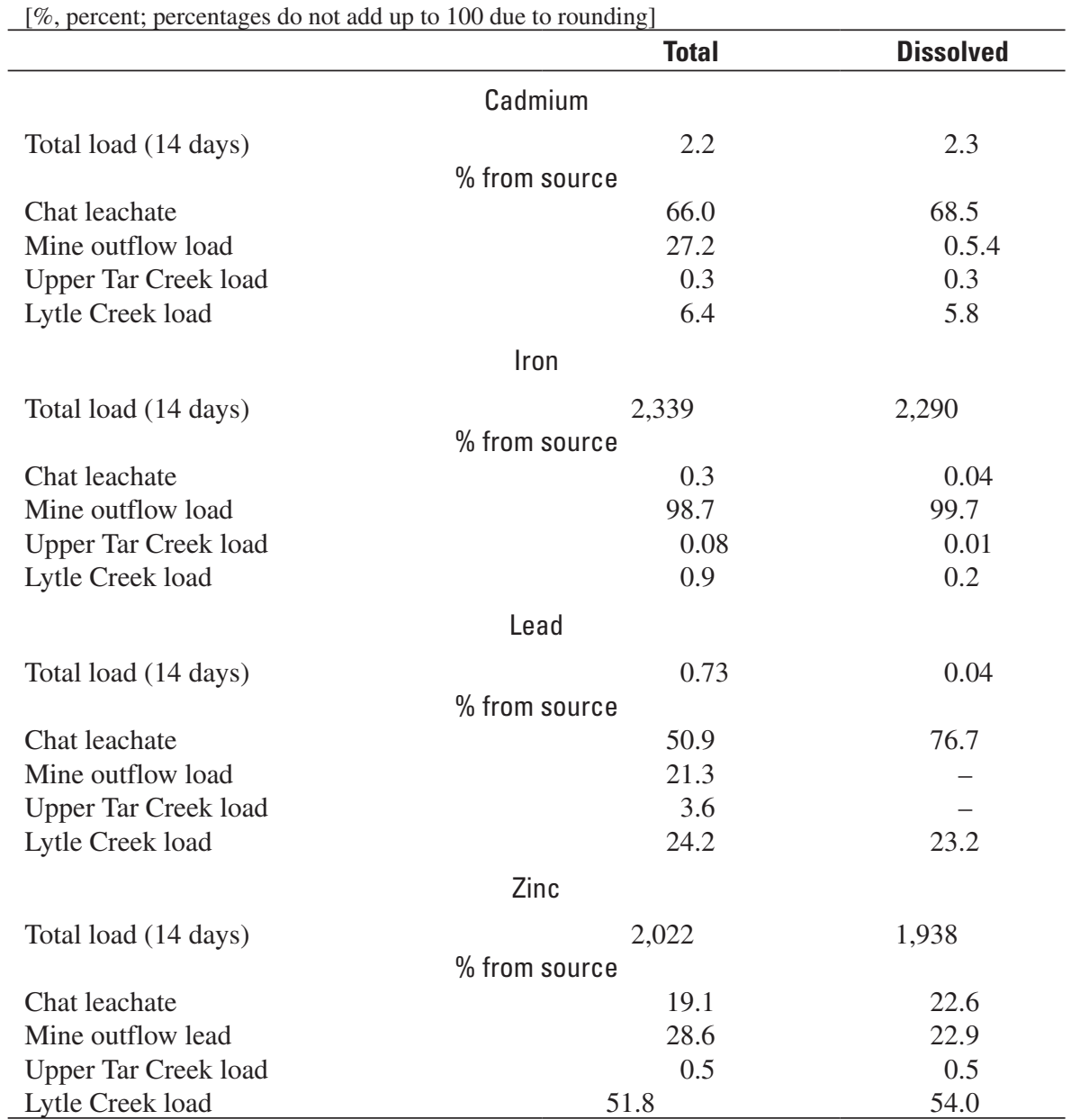

Table 9. Summary statistics of metal loads and streamflow from Tar Creek above Douthat Bridge, near Cardin, 0klahoma (071850875) sampled from August 16, 2005, to August 29, 2005, in the Picher mining district, Ottawa County, Oklahoma.

$\left[\mathrm{ft}^{3} / \mathrm{s}\right.$, cubic foot per second; lb/day, pound per day]

\begin{tabular}{|c|c|c|c|c|c|c|c|c|c|}
\hline $\begin{array}{l}\text { Summary } \\
\text { statistics }\end{array}$ & $\begin{array}{c}\text { Streamflow } \\
\left(\mathrm{ft}^{3} / \mathrm{s}\right)\end{array}$ & $\begin{array}{c}\text { Total } \\
\text { cadmium } \\
\text { (lb/day) }\end{array}$ & $\begin{array}{c}\text { Dissolved } \\
\text { cadmium } \\
\text { (lb/day) }\end{array}$ & $\begin{array}{l}\text { Total iron } \\
\text { (lb/day) }\end{array}$ & $\begin{array}{l}\text { Dissolved } \\
\text { iron } \\
\text { (lb/day) }\end{array}$ & $\begin{array}{c}\text { Total lead } \\
\text { (lb/day) }\end{array}$ & $\begin{array}{c}\text { Dissolved } \\
\text { lead } \\
\text { (lb/day) }\end{array}$ & $\begin{array}{c}\text { Total zinc } \\
\text { (lb/day) }\end{array}$ & $\begin{array}{c}\text { Dissolved } \\
\text { zinc } \\
\text { (lb/day) }\end{array}$ \\
\hline Maximum & 1.62 & 0.287 & 0.306 & 5.47 & 0.428 & 0.127 & 0.016 & 522 & 539 \\
\hline Minimum & 0.188 & 0.062 & 0.062 & 0.432 & 0.065 & 0.004 & - & 20.1 & 19.7 \\
\hline Mean & 0.480 & 0.114 & 0.120 & 1.48 & 0.143 & 0.029 & - & 102 & 105 \\
\hline
\end{tabular}


One streamflow measurement was collected on August 16 from runoff at the Western location, (site 071850818). Estimated streamflow at site 071850818 on August 16 was $<0.01$ cubic foot per second $\left(\mathrm{ft}^{3} / \mathrm{s}\right)$. Following August 16 flow diminished to levels that could no longer be measured.

Seven streamflow measurements were made at each site in Tar Creek Study Segment. Streamflow measurements were made on August 16, 18, 20, 22, 24, 26, and 29. Measured streamflows within Tar Creek Study Segment ranged from $<0.01$ to $2.62 \mathrm{ft}^{3} / \mathrm{s}$. No streamflow measurements were made in Tar Creek Study Segment after August 29 as water levels and streamflow values had returned to pre-event levels.

Metals, with the exception of iron, at the Western location generally were predominate in the dissolved phase. Total cadmium concentration of the sample collected at the Western location, (site 071850818) was 95.3 micrograms per liter $(\mu \mathrm{g} / \mathrm{L})$, dissolved cadmium concentration was $103 \mu \mathrm{g} / \mathrm{L}$. Total iron concentration was $182 \mu \mathrm{g} / \mathrm{L}$, while dissolved iron concentration was $47 \mu \mathrm{g} / \mathrm{L}$. Total and dissolved lead concentrations were 170 and $117 \mu \mathrm{g} / \mathrm{L}$, respectively. Total zinc concentration was $1,760 \mu \mathrm{g} / \mathrm{L}$ and dissolved zinc concentration was $1,730 \mu \mathrm{g} / \mathrm{L}$.

Cadmium and zinc at Tar Creek Study Segment generally were predominate in the dissolved phase, while total iron and lead generally were predominate. Total cadmium concentrations of samples collected from Tar Creek Study Segment ranged from 0.83 to $62 \mu \mathrm{g} / \mathrm{L}$ with a mean of $21.18 \mu \mathrm{g} / \mathrm{L}$. Total iron concentrations ranged from $170 \mu \mathrm{g} / \mathrm{L}$ to $38,000 \mu \mathrm{g} / \mathrm{L}$ with a mean of $7,924 \mu \mathrm{g} / \mathrm{L}$. Total lead concentrations ranged from $0.50 \mu \mathrm{g} / \mathrm{L}$ to $26.7 \mu \mathrm{g} / \mathrm{L}$ with a mean of $7.68 \mu \mathrm{g} / \mathrm{L}$. Total zinc concentrations ranged from 1,670 to $59,900 \mu \mathrm{g} / \mathrm{L}$ with a mean of $14,548 \mu \mathrm{g} / \mathrm{L}$.

No loading values were calculated for the Western location, (site 071850818). Low streamflow value, $\left(<0.01 \mathrm{ft}^{3} / \mathrm{s}\right)$, indicates that during the sampling period metal load contributions would have been negligible.

Metals loading to Tar Creek Study Segment were calculated based on instantaneous streamflow and metals concentrations. Total cadmium loading to Tar Creek from chat leachate ranged from 0.062 to 0.212 pound per day (lb/day) with a mean of $0.104 \mathrm{lb} /$ day. Total iron loading to Tar Creek from chat leachate ranged from $<0.001$ to $0.814 \mathrm{lb} /$ day. Total lead loading to Tar Creek from chat leachate ranged from 0.003 to $0.036 \mathrm{lb} /$ day with a mean of $0.014 \mathrm{lb} /$ day. Total zinc loading to Tar Creek from chat leachate ranged from 10.6 to $47.9 \mathrm{lb} /$ day with a mean of $26.2 \mathrm{lb} /$ day.

Total cadmium loading to Tar Creek from mine outflow ranged from 0.001 to $0.104 \mathrm{lb} /$ day with a mean of $0.042 \mathrm{lb} /$ day. Total iron loading to Tar Creek from mine outflow ranged from 139 to $183 \mathrm{lb}$ /day with a mean of $155 \mathrm{lb}$ /day. Total lead loading to Tar Creek from mine outflow ranged from $<0.001$ to $0.024 \mathrm{lb} /$ day. Total zinc loading to Tar Creek from mine outflow ranged from 12.1 to $136 \mathrm{lb}$ /day with a mean of $39.8 \mathrm{lb}$ /day.

Total metal loads for Tar Creek Study Segment were estimated for the period beginning August 16 and ending August
30 and the percentage from each source calculated. The four sources of calculated metal loads are from Tar Creek and Lytle Creek entering the study segment, from chat pile leachate, and from mine outflow from old Lytle Creek. About 68 percent of total and dissolved cadmium was from chat leachate and about 26 percent was from mine outflow. A total of about 99 percent of total and dissolved iron loading was from mine outflow. About 51 percent of total lead loading was from chat leachate, 21 percent from mine outflow, and 24 percent from Lytle Creek. About 77 percent of dissolved lead loading was from chat leachate. About 19 percent of total zinc loading was from chat leachate, 29 percent of total zinc loading was from mine outflow, and 52 percent of total zinc loading was from Lytle Creek.

\section{References Cited}

Brichta, L.C., 1960, Catalog of recorded exploration drilling and mine workings, Tri-State zinc-lead district, Missouri, Kansas, and Oklahoma: U.S. Bureau of Mines Information Circular IC7993, 13 p.

Faires, L.M., 1993, Methods of analysis by the U.S. Geological Survey National Water Quality Laboratory-Determination of metals in water by inductively coupled plasma-mass spectrometry: U.S. Geological Survey Open-File Report 92-634, 28 p.

Ferderer, D.A., 1996, National overview of abandoned mine land sites utilizing the Minerals Availability System (MAS) and geographic information system (GIS) technology: U.S. Geological Survey Open-File Report 96-549, 39 p.

Keheley, Ed, and Pritchard, Mary Ann, 2000, Report to Governor Keating's Tar Creek Superfund Task Force by the Subsidence Subcommittee: Oklahoma Department of Environmental Quality, 75 p.

Gibson, A.M., 1972, Wilderness bonanza-The Tri-State district of Missouri, Kansas, and Oklahoma: Norman, Okla., University of Oklahoma Press, 362 p.

Gibson, A.M., 1982, Lead and zinc in Morris, J.W., ed., Drill bits, picks, and shovels-A history of mineral resources in Oklahoma: Oklahoma City, Okla., Oklahoma Historical Society, $201 \mathrm{p}$.

McKnight, E.T., and Fischer, R.P., 1970, Geology and ore deposits of the Picher field, Oklahoma and Kansas: U.S. Geological Survey Professional Paper 588, 165 p.

Oklahoma Department of Environmental Quality, 2004, Oklahoma plan for Tar Creek: accessed June 6, 2006, at http://inhofe.senate.gov/superfundl.pd] 
Rantz, S.E., and others, 1982, Measurement and computation of streamflow-Volume 1, Measurement of stage and outflow: U.S. Geological Survey Water-Supply Paper 2175, $284 \mathrm{p}$.

Robertson, D., 2006, Hard as the rock itself, place and identity in the American mining town: University Press of Colorado, $216 \mathrm{p}$.

State of Oklahoma, 2000, Governor Frank Keating's Tar Creek Superfund Task Force, Final Report: Office of Secretary of Environment, October 1, 2000, 27 p.

State of Oklahoma, 2002, Oklahoma Plan for Tar Creek, accessed on 9/28/2007 at http://www.deq.state.ok.us/lpdnew/ Tarcreek/Okplan.pdd
Wilde, F.D., and Radtke, D.B., Gibs, Jacobs, and Iwatsubo, R.T., eds., 1998, National field manual for the collection of water-quality data-Cleaning of equipment for waterquality samples: U.S. Geological Survey Techniques of Water-Resources Investigations, book 9, chap. A3, variously paged.

Wilde, F.D., Radtke, D.B., Gibs, Jacobs, and Iwatsubo, R.T., eds., 1999, National field manual for the collection of water-quality data-Collection of water-quality samples: U.S. Geological Survey Techniques of Water-Resources Investigations, book 9, chap. A4, variously paged. 
Prepared by Lafayette Publishing Service Center. Edited by Lyn Osburn.

Illustrations by Jeff Hartley.

Layout and design by Lyn Osburn.

For more information concerning the research described in this report, contact:

U.S. Geological Survey

202 NW 66th St., Bldg. 7

Oklahoma City, OK 73116

(405) $810-4400$

http://ok.water.usgs.gov 